\title{
Evidence of Paleoproterozoic phosphogenesis in the Salvador-Curaçá Orogen (Tanque Novo-Ipirá Complex), northeastern São Francisco Craton, Brazil
}

\author{
Tatiana Silva Ribeiro ${ }^{*}$ (D), Aroldo Misi ${ }^{2}$ (D), Luís Rodrigues dos Santos de Oliveira ${ }^{2}$ (D),

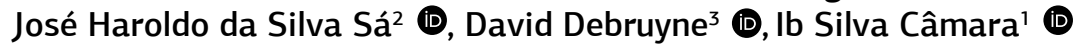

\begin{abstract}
This paper analyzes mineralogical, geochemical, and geochronological aspects, along with the effect of hydrothermal/metasomatic overprints, to identify the presence of primary phosphate as well as depositional and paleoenvironmental conditions in marble and calcsilicate sequences recrystallized under transitional amphibolite-granulite metamorphic conditions in the Tanque Novo-Ipirá Complex within the Salvador-Curaçá Orogen, northeastern São Francisco Craton, state of Bahia, Brazil. Petrographic studies have identified up to 10 vol.\% disseminated apatite and whole-rock $\mathrm{P}_{2} \mathrm{O}_{5}$ contents up to $3.2 \mathrm{wt}$.\%. Post-depositional events affected the lithofacies to varying degrees. Late hydrothermalism did not modify the rare earth element and yttrium (REEY) patterns considerably. When normalized to Post-Archean Australian Shale (PAAS), these lithofacies are marked by flat pattern REEY, true negative Ce anomalies, and positive Y and Gd. The highly variable $\mathrm{Eu}$ anomalies were inherited from the source composition but may have been affected by interaction with fluids. U-Pb LA-ICP-MS (laser ablation multicollector inductively coupled plasma mass spectrometry) ages indicate a maximum depositional age of $2128 \mathrm{Ga}$, as well as Paleoproterozoic and Neoarchean sources. Samples with anomalous phosphorus show Y/Ho ratios $>30$ and $\mathrm{Ce} / \mathrm{Ce}{ }^{*}$ anomalies between 0.53 and 1.0 with an average of 0.70 , suggesting a sub-oxic environment for phosphate precipitation.
\end{abstract}

KEYWORDS: phosphogenesis; Paleoproterozoic; Tanque Novo-Ipirá Complex; São Francisco Craton; paleobasin.

\section{INTRODUCTION}

Calcsilicate rocks and marbles are common in metamorphic terrains associated with orogenic belts and are often intercalated with other pelitic and siliciclastic metasediments. The decarbonation reactions that occur during the medium- to high-grade metamorphism of these rocks generate a variety of $\mathrm{Ca}-\mathrm{Mg}$-rich silicates, such as zoisite, tremolite, grossular, amphibole, diopside, and olivine (Bucher and Grapes 2010).

These rocks are of great importance due to their metallogenic potential, especially for phosphate and skarn-type

\footnotetext{
${ }^{1}$ Graduate degree in Geology, Institute of Geosciences, Universidade Federal da Bahia - Salvador (BA), Brazil. E-mails: tatiana_geologia@ yahoo.com.br, ibsilvacamara@hotmail.com

${ }^{2}$ Group of Metallogenesis, Metallogenetic Models, and Mineral Exploration, Geophysics and Geology Research Center, Universidade Federal da Bahia - Salvador (BA), Brazil. E-mails: aroldo.misi@gmail. com, rodrigues.oliveira@hotmail.com, haroldo.sa@gmail.com ${ }^{3}$ Geological Engineering Center, Universidade Federal de Pelotas Pelotas (RS), Brazil. E-mail: davidd3bruyn3@gmail.com.

${ }^{*}$ Corresponding author.

Supplementary data
}

Supplementary data associated with this article can be found in the online version: Supplementary Figure 1 and Supplementary Figures 2 and 3. deposits, besides calcite mining. This complex mineralogical association can preserve several original geochemical signatures that, combined with field data, can be used for reconstructions, determination of paleoenvironmental conditions, and stratigraphic correlations. The most widespread geochemical tools used for these purposes include rare earth elements and yttrium (REEY) patterns, stable isotopes (carbon, oxygen, and sulfur), ${ }^{87} \mathrm{Sr} /{ }^{86} \mathrm{Sr}$ isotopes, and studies involving francolite or carbonate-fluorapatite, the main ore minerals in marine phosphorites (Veizer et al. 1999, Bau 1993, Papineau 2010, Nelson et al. 2010, Pufahl and Hiatt 2012, Swart 2015).

Biogenic phosphorites are formed in marine environments associated with a complex phosphogenic system, controlled by the availability of oxygen in the paleobasin and by the flow of continental iron- and phosphorus-rich sediments (Glenn et al. 1994, Papineau et al. 2013). However, the first Paleoproterozoic phosphogenic pulse produced phosphorites that may contain less than 18 wt.\% $\mathrm{P}_{2} \mathrm{O}_{5}$ (Pufahl 2010, Papineau 2010, Papineau et al. 2013, Hiatt 2015).

The oldest sedimentary phosphate mineralizations occurred in the Paleoproterozoic age and are related to the global Great Oxidation Event (GOE) that started around 2.5 Ga (Pufahl 2010, Papineau 2010). The main Paleoproterozoic deposits are located in Russia, China, North America (Baraga Group between Canada and the United States), Finland, North Korea, Africa, and India (Papineau 2010). 
This paper examines the primary phosphorus mineralization potential of calcsilicate rocks and marbles in the Paleoproterozoic Tanque Novo-Ipirá Complex. This complex is composed of calcsilicate rocks, marbles, metapsammites, banded iron formations (BIFs), and paragneisses, metabasites, and meta-ultrabasites metamorphosed at amphibolite to granulite facies conditions. We investigated the calcsilicate rocks and marbles of the complex using petrographic, mineralogical, geochemical, and geochronological (U-Pb laser ablation multicollector inductively coupled plasma mass spectrometry - LA-ICP-MS) methods in order to identify the geological conditions in which these rocks were generated and identify the maximum deposition age of this Paleoproterozoic sequence.

The relevance of the present work is highlighted by the growing agricultural need for phosphorus and its derived fertilizer products, given the growing world population, which drives the search for new phosphate deposits, including those in intensely metamorphosed Paleoproterozoic basins.

\section{REGIONAL AND LOCAL GEOLOGICAL CONTEXT}

The Archean São Francisco Craton (SFC), consolidated during the Transamazonic (Orosirian) cycle at the end of the Paleoproterozoic, was partially reworked in the Neoproterozoic and Cambrian, during the Brazilian cycle (Alkmim et al. 1993, Barbosa and Sabaté 2003, Barbosa and Dominguez 2006). The study area is located in the northeast portion of the SFC, in the Tanque Novo-Ipirá Complex within the northern segment Itabuna-Salvador-Curaçá Orogen (Fig. 1). The Itabuna-Salvador-Curaçá Orogen was formed over a time span of about 200-300 million years, during the Paleoproterozoic, when a block of the same name collided with other Archean-age blocks (Gavião, Jequié, and Serrinha blocks), leading to the formation of an important mountain chain (Barbosa and Sabaté 2003).

The Salvador-Curaçá Orogen is located in the eastern region of Bahia, extending for approximately $700 \mathrm{~km}$ from north to south. It corresponds to a ductile shear belt that was generated in a transpressive regime during the Paleoproterozoic collision of the Gavião, Jequié, Salvador-Curaçá, and Serrinha blocks, and evolved progressively during successive compressive episodes (Kosin et al. 2003). Transient, ductile, sinistral shear zones with westward vergence in the Gavião Block, as well as corresponding shear zones with eastward vergence in the Serrinha Block (Leite 2002), delimit this orogen. Barbosa and Sabaté (2003) interpret these features as asymmetrical positive flower structures generated during the final Paleoproterozoic orogeny.

The Salvador-Curaçá Orogen can be subdivided into three main domains in its northern segment (Melo et al., 1991): the Caraíba Complex, the São José do Jacuípe Suite, and the Tanque Novo-Ipirá Complex. Several granitoid suites are present and classified according to deformation phases besides Cenozoic cover rocks. Sensitive High-Resolution Ion Microprobe (SHRIMP) U-Pb ages obtained in tonalitic and enderbitic granulites from the Caraíba Complex revealed two age populations: $2.7-2.6 \mathrm{Ga}$ and 2.08-2.07 Ga (Silva et al. 1997), preserved in zircon cores and rims, respectively. The 2.7-2.6 Ga ages are interpreted as a period of island arc magmatism, whereas the 2.08-2.07 Ga ages are related to high-grade metamorphism (Silva 1996).

Melo et al. (1991) classified the Ipirá Complex into five different units:

- Pintadas;

- Serra do Camisão;

- Juazeirinho;

- Angico;

- Umbuzeiro.

Out of these five units, only the Pintadas and Serra do Camisão occur in the study area. The lower sequence is regarded as an oceanic floor sequence associated with paragneisses, kinzigites, and metabasites of the Pintadas Unit. The upper Serra do Camisão Unit includes marbles and calcsilicate rocks, both lithofacies hosting apatite deposits, in addition to iron formations, graphite schists, and quartzites and the absence of alumina-rich gneisses (Melo et al. 1991).

Kosin et al. (2003) combined the Tanque Novo Group and the Ipirá Complex into the Tanque Novo-Ipirá Complex, understood as a metavolcano-sedimentary sequence developed between the Archean and Paleoproterozoic that experienced high-grade amphibolite to granulite facies metamorphism. It was subdivided into six informal units, based on their lithological assemblages:

- kinzigitic or garnet-rich biotite gneisses and migmatites, associated with calcsilicate, quartzite, BIF, graphitic rocks, and metamorphic and meta-ultramafic rocks;

- calcsilicate rocks, quartzite, marbles, amphibolite, and BIF;

- garnetiferous hornblende-biotite gneiss, with quartz-feldspathic bands and orthopyroxene, interspersed with amphibolitic levels;

- graphite gneiss associated with calcsilicate rocks with intercalations of ferrous quartzite, migmatized gneiss, kinzigitic gneiss, and quartz-feldspathic gneiss, with or without garnet;

- banded gneiss, with alternation of granitic-granodioritic and gabbroic-dioritic bands, and intercalations of tonalitic gneiss, amphibolite, and subordinate calcsilicate rocks;

- orthopyroxene quartz-feldspathic gneiss, with or without garnet and rare biotite.

These rocks experienced different degrees of migmatization and show diffuse contact with granitoid bodies.

Depleted mantle $\mathrm{Nd}$ model ages of alumina-rich gneisses in the Tanque Novo Group (Curuçá River Valley) indicate model ages of $2.6 \mathrm{Ga}$ (Oliveira et al. 2002).

The study area is characterized by carbonate, calcsilicate, and siliciclastic lithofacies occurring in discontinuous narrow strips of up to 10 kilometers wide and showing strong deformation (mainly folding), geometrically consistent with regional structures (Fig. 2). The current structural situation reflects a 


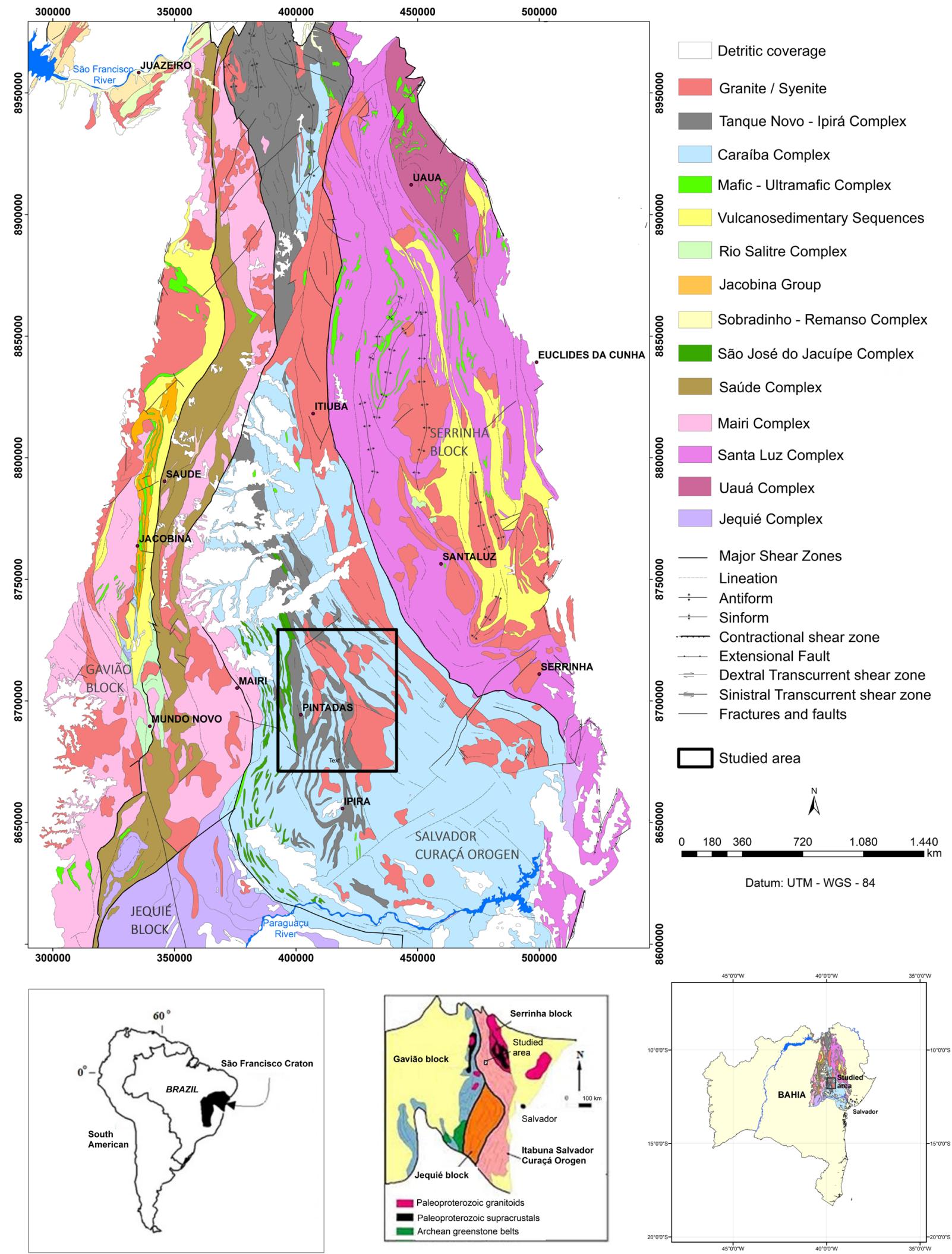

Figure 1. Simplified geological map of the northern segment of the Salvador-Curaçá Orogen (after Oliveira et al. 2010), showing the location of the study area.

complex polyphase deformation involving crustal shortening. These lithofacies emerge discontinuously in N-S to NNWSSE-oriented lenticular or spindle-shaped bodies, generally with subvertical dipping layers.
The marbles in the metasedimentary sequence gradually grade into calcsilicate rocks and metapsammites, depending on the relative amount of detrital material. The units in the study area can be subdivided into: 
- Marbles;

- Calcsilicate (gneiss and granofels);

- Metapsammite;
- Skarn;

- Graphite schist;

- Granitoids.

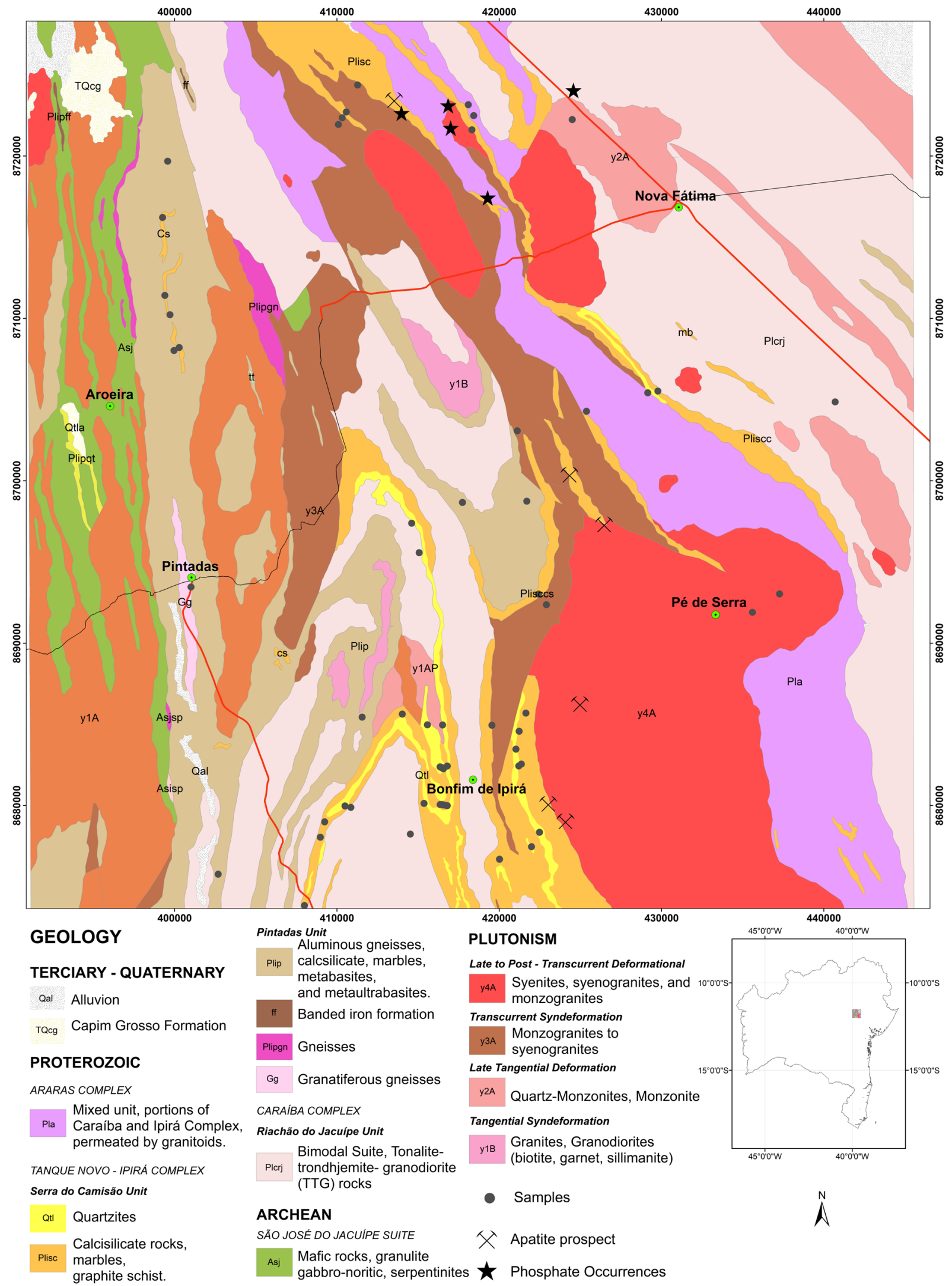

Source: Modified from Melo et al. (1991).

Figure 2. Geological map of the study area with the indication of points of samples collected during fieldwork. 
The orthogneisses of the Caraíba Complex constitute the basement rocks. They are associated with intense plutonism related to different deformation phases. The $\mathrm{N}$-S-oriented ductile and brittle deformation structures with dips of $45-85^{\circ}$ are most easily identified in calcsilicate rocks. Figure 3 shows two geological sections in the Bonfim de Ipirá and southern Ipirá regions, respectively.

\section{ANALYTICAL METHODS}

Samples - free of visible effects of weathering, alteration, and late veins - were collected from a representative section between the towns of Ipirá and Pintadas. In total, they consisted of 8 marbles, 28 calcsilicate rock samples, 2 graphite schists, and 4 metapsammites.

Tests for the presence of phosphate in rock samples were performed with ammonium molybdate and $\mathrm{HCl}$ (hydrochloric acid) or $\mathrm{HNO}_{3}$ (nitric acid) during fieldwork. This qualitative colorimetric test allows detecting the presence of $\mathrm{P}_{2} \mathrm{O}_{5}$ anomalies through the formation of an ammonium phosphomolybdate precipitate with an intense yellow to greenish-yellow color.

Petrographic studies were carried out with an Olympus BX60 petrographic microscope at the Microscopy Laboratory of the Geosciences Institute of the Universidade Federal da Bahia. X-ray diffraction (XRD) analyses were performed with a second-generation Bruker Diffractometer D2 Phaser at the Mineral Technology Laboratory - X-ray of the Universidade Federal da Bahia (LAPAG) to identify the type of carbonate (calcite and/or dolomite), apatite, and serpentine present. The Diffrac Suite EVA software was used for XRD data processing. Thin sections were also investigated with a JEOL JSM-6610LV Scanning Electron Microscope (SEM) at the Electron Microscopy Multiuser Laboratory of the Universidade Federal da Bahia (LAMUME); graphs were generated with the AZtec software.

Geochemical studies were prepared and analyzed in the SGS Geosol Laboratory in Belo Horizonte, Minas Gerais. Marbles and calcsilicate rock samples, typically weighing $250 \mathrm{~g}$, were crushed to $3 \mathrm{~mm}$ particles, homogenized, quartered in Jones, and sprayed on a 150-mesh steel mill.

Major-element abundances $\left(\mathrm{SiO}_{2}, \mathrm{Ti}_{2} \mathrm{O}, \mathrm{Al}_{2} \mathrm{O}_{3}, \mathrm{MgO}\right.$, $\mathrm{Fe}_{2} \mathrm{O}_{3 \mathrm{t}}, \mathrm{MnO}, \mathrm{CaO}, \mathrm{Na}_{2} \mathrm{O}, \mathrm{K}_{2} \mathrm{O}$, and $\mathrm{P}_{2} \mathrm{O}_{5}$ ) were measured using X-ray fluorescence. In this analysis, $0.5 \mathrm{~g}$ of the samples was fully digested by fusion with lithium tetraborate in a Vulcan automatic machine at $1,000^{\circ} \mathrm{C}$. The analysis was performed on a fused tablet by X-ray fluorescence spectrometry, WDXRF type, simultaneous PANalytical Axios Fast model, obtaining results with a natural basis.

Trace elements (Ba, Rb, Ga, Zr, Sr, Cr, Ni, Co, and Y) and rare earth elements (REE) were determined by complete digestion by fusion in a muffle at $950^{\circ} \mathrm{C}$, with lithium metaborate $\left(\mathrm{LiBO}_{2}\right)$, dissolving with an acid solution of nitric acid and tartaric acid $\left(\mathrm{HNO}_{3}\right.$ and $\left.\mathrm{C}_{4} \mathrm{H}_{6} \mathrm{O}_{6}\right)$. Trace elements were read by ICP-Optical Emission Spectrometry (ICP-OES), Optima 7300DV model. This solution also quantified REEs read by ICP-MS, NexION 300X ICP-MS model. REEY
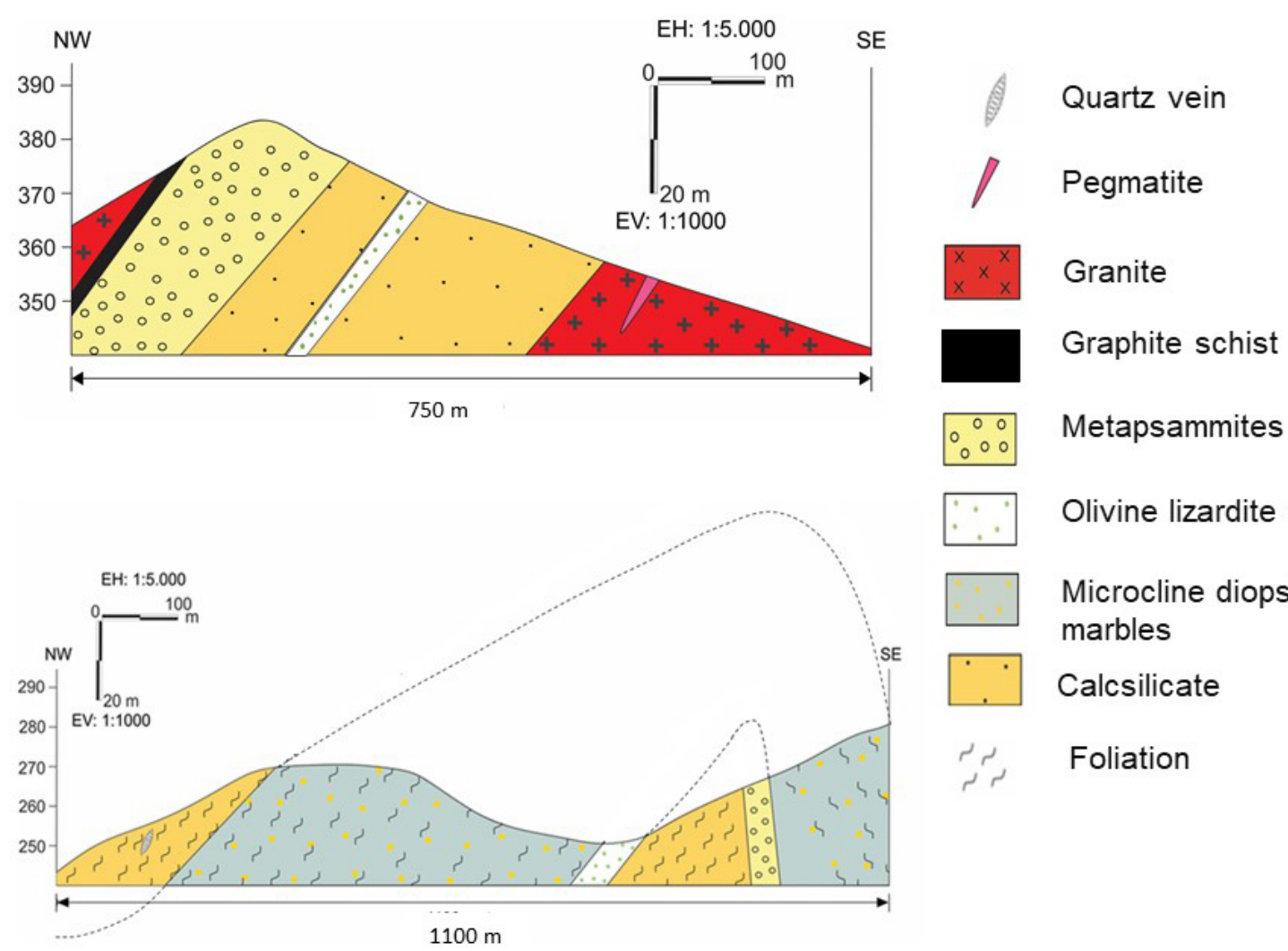

Olivine lizardite marbles

Microcline diopside marbles

Calcsilicate

Foliation

Figure 3. Geological sections of the Serra do Camisão Unit. (A) Bonfim de Ipirá region. (B) Southern Ipirá region, calcsilicate rocks and marbles with microcline and diopside are herein represented with foliation. This section shows a compositional gradation between marbles and calcsilicate rocks up to quartzite. 
concentrations were normalized according to the average PostArchean Australian Shale (PAAS) composition reported by McLennan (1989).

Handpicked zircons were mounted in $2-\mathrm{cm}$ diameter epoxy resin and polished to suitably generate reflected and cathodoluminescence images in order to characterize their internal complexities and choose the best location for the subsequent spot analyses.

The zircon U-Pb LA-ICP-MS was performed at the Institute of Geosciences of the Universidade de São Paulo at the HighResolution Geochronology Laboratory (GEOLAB), using the Thermo-Fisher Neptune LA-ICP-MS, equipped with a $193 \mathrm{~nm}$ ArF laser photon system. The $29-\mu \mathrm{m}$ diameter spot works with a frequency of $6 \mathrm{~Hz}$ and intensity of $6 \mu \mathrm{J}$. The ablated material was carried by $\operatorname{Ar}(\sim 0.7 \mathrm{~L} / \mathrm{min})$ and $\mathrm{He}(\sim 0.6 \mathrm{~L} / \mathrm{min})$ in analyses of 60 cycles of $1 \mathrm{~s}$ (more details can be found in Sato et al. 1995).

The analytical procedure of the U-Pb method included the analysis of NIST (National Institute of Standards) synthetic glass standards, external reference materials, and blanks. Both NIST glass and external reference materials were used to normalize the ${ }^{207} \mathrm{~Pb} /{ }^{206} \mathrm{~Pb}$ ratio, whereas the external reference material was used to normalize the ${ }^{206} \mathrm{~Pb} /{ }^{238} \mathrm{U}$ ratio. Residual common $\mathrm{Pb}$ and instrumental discrimination were corrected using the known terrestrial composition (Stacey and Kramers 1975) and the reference zircon standard (GJ-1) (Jackson et al.2004), respectively. Data are portrayed in a concordia diagram generated in the ISOPLOT 4 software (Ludwig 2003).

\section{FIELD ASPECTS AND PETROGRAPHY}

\section{Marbles}

The greenish-white to grayish and sometimes orange-colored marbles crop out as isolated bodies associated with calcsilicate rocks in the Serra do Camisão Unit. Most marbles are medium- to coarse-grained, except for the subordinate fine- to medium-grained white serpentine-bearing marble. These rocks have a massive appearance, except for the orange-colored marble, which displays orange calcite bands intercalated with diopside bands (Figs. 4A and 4B). Petrographically, the marbles were separated into two groups according to the textural and compositional characteristics described below.

\section{Group 1}

Group 1 marbles consist of calcite/dolomite (30-50 vol.\%) associated with olivine (5-20 vol.\%), serpentine (10-50 vol.\%), garnet (2-10 vol.\%), diopside (5-20 vol.\%), talc (10 vol.\%), opaque minerals (2 vol.\%), tremolite (10-20 vol.\%), and apatite. Calcite presents a poikiloblastic sieve texture included in a medium-grained matrix and curved contacts with phases belonging to the serpentine and garnet group. Apatite, olivine, and garnet occur as inclusions. Preserved olivine crystals are subdiomorphic, intensely fractured, and contain inclusions of opaque and serpentine minerals. Phases of the serpentine group constitute about 30 vol. $\%$ of the average total rock volume in Group 1. The mesh-type texture formed by serpentine surrounding central zones with relict olivine can be visualized in Figure 4C. Rims or microveins filled with opaque minerals are common. Where the serpentinization process is intense, the mesh texture evolves to a curtain-like texture (bipartite subparallel veins); relict olivine cores are absent, and serpentine recrystallizes and is replaced by talc (Fig. 4D).

\section{Group 2}

Group 2 marbles contain calcite (35-40 vol.\%), microcline (25-30 vol.\%), diopside (25-35 vol.\%), tremolite (10-15 vol.\%), hornblende (5-10 vol.\%), chlorite (5 vol.\%), zircon $(<5$ vol.\%), titanite ( $<5$ vol.\%), and opaque minerals ( $<5$ vol.\%). Calcite makes up about $40 \%$ of the average total rock volume in Group 2, and subdiomorphic calcite crystals exhibit straight contacts with each other. Subdiomorphic to xenomorphic microcline crystals occur only in Group 2 and occasionally preserve tartan twinning. Microcline is moderately to intensely sericitized and contains zircon inclusions. It is associated with calcite, in curved contacts filling the interstitial areas between the calcite crystals (Fig. 4E). Diopside is present as xenomorphic crystals partially transformed to tremolite in re-entrant contacts between diopside and hornblende (Fig. 4F). Hornblende is present as non-oriented subdiomorphic, prismatic, and chloritized crystals with opaque and titanite inclusions in re-entrant contacts with diopside. Figure 4F illustrates a reaction corona with a nucleus consisting of tremolitized diopside, recognizable by its lower relief and fibrous aspect, formed during hydrothermal alteration. Hornblende is altered to chlorite at the edges of the reaction zone.

The XRD analysis confirmed the presence of dolomite in Group 1 and classified the serpentine as lizardite (Suppl. 1). SEM analysis allowed investigating the calcite-lizardite $\left[\mathrm{Mg}_{3} \mathrm{Si}_{2} \mathrm{O}_{5}(\mathrm{OH})_{4}\right]$ contacts in more detail, as illustrated in Figure 5A, which also shows a serpentinized olivine pseudomorph inclusion in calcite. Dolomite crystals show calcite intergrowths (Fig. 5B). The presence of phlogopite was detected by SEM analysis; this mineral displays slightly curved contacts with calcite and is partially chloritized at the rims, as evidenced by the difference in texture and chemical composition at its edges (Fig. 5C).

Based on their compositional and modal characteristics, marbles of Group 1 were classified as lizardite marbles and olivine-lizardite marbles. If present ( $<5$ vol.\%), garnet was included in the name (garnet lizardite marble). Group 2 marbles were classified as diopside marbles and microcline marbles.

\section{Calcsilicates}

Calcsilicates occur as lenticular and discontinuous bodies affected by multiple deformation phases, associated with quartzites and marble lenses. They are fine- to medium-grained, greenish-white to grayish, and show clear foliation planes (Fig. 6A).

These calcsilicates contain diopside (15-55 vol.\%), tremolite (15-35 vol.\%), plagioclase (10-20 vol.\%), K-feldspar (10-20 vol.\%), quartz (5-22 vol.\%), biotite (2 vol.\%), titanite ( $<5$ vol.\%), hornblende (2-10 vol.\%), opaque ( $<5$ vol.\%), zircon ( $<5$ vol.\%), calcite (5-20 vol.\%), and apatite. Occasionally, a compositional banding can be observed, characterized by 

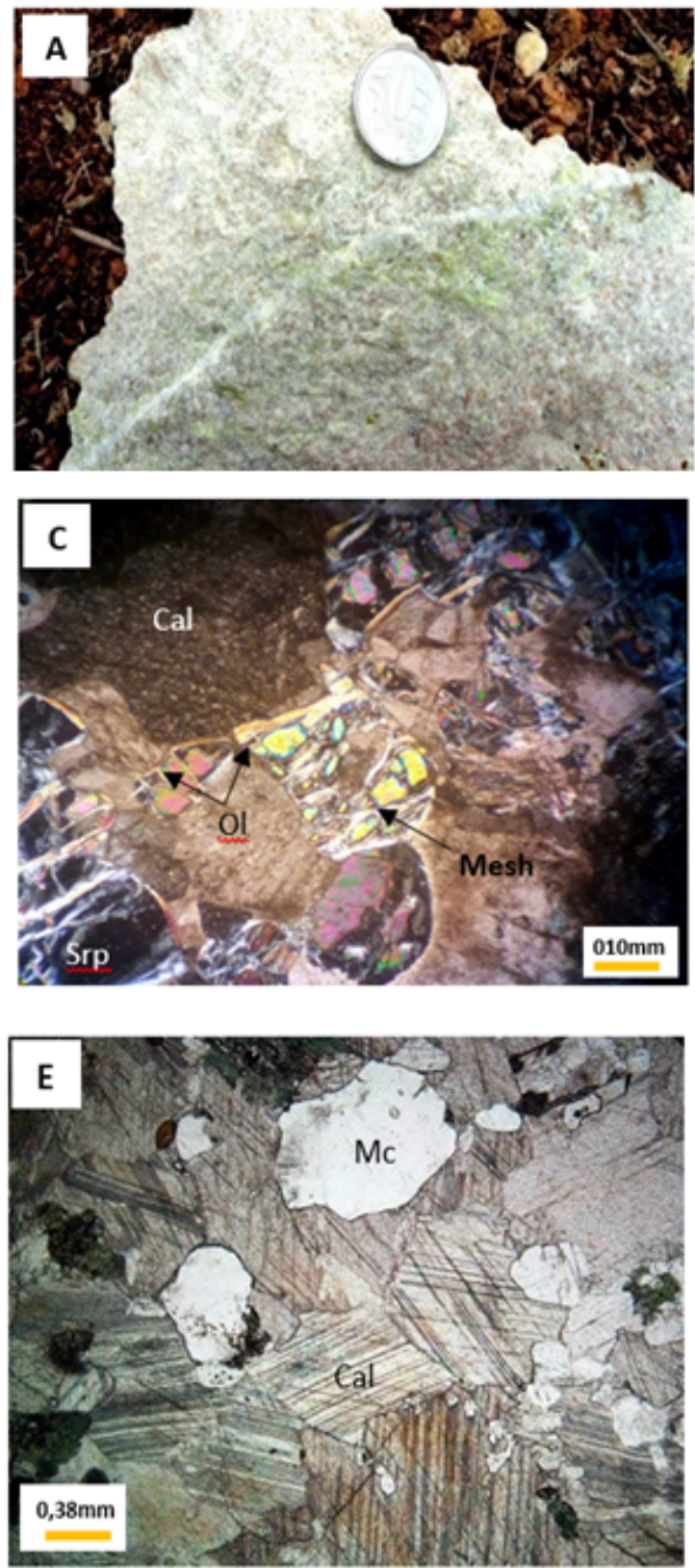
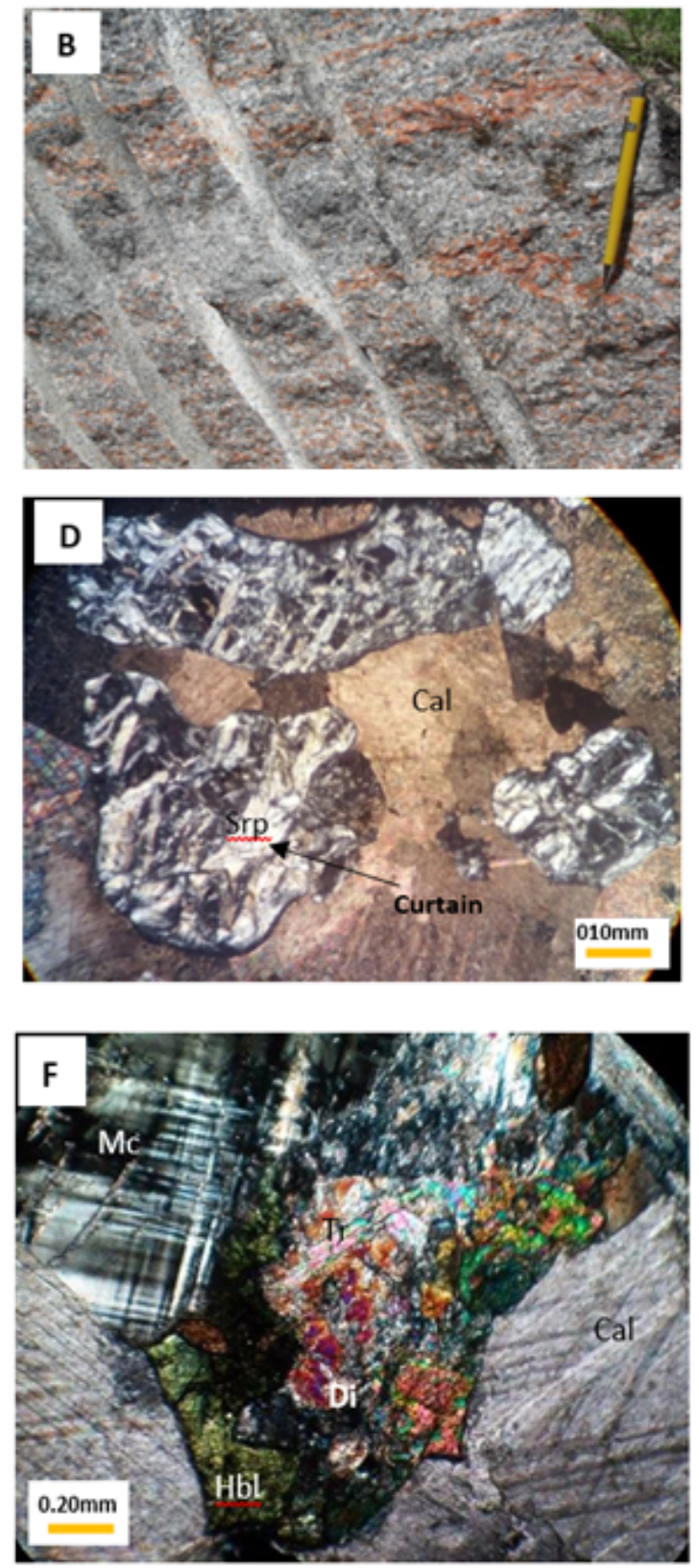

Figure 4. (A) Calcite and greenish-white serpentine marbles. (B) Outcrop showing a banded marble with alternating orange calcite layers and dark diopside-bearing layers (MM-TR-293 sample). (C) Mesh texture evidenced by serpentinized (Srp) olivine (Ol) associated with calcite (Cal) (XPL). (D) Curtain-type texture within serpentinized olivine pseudomorphs (XPL). (E) Marble with polygonal granoblastic texture (Mc) (PPL). (F) Reaction corona between diopside (Di), tremolite ( $\mathrm{Tr}$ ), and hornblende (Hbl) (PPL). XPL: cross-polarized light; PPL: plane-polarized light.

alternating bands of diopside and/or tremolite and bands of variable compositions ranging from quartz to feldspar + quartz (calcsilicate gneisses). Massive occurrences are also present, discretely foliated or exclusively composed of diopside, hornblende, tremolite, and plagioclase denominated tremolite-diopside-granofels. Figure 6B shows a positive phosphate test.

Calcsilicate gneisses and tremolite-diopside-granofels form skarns in hydrothermally altered contact zones and potassic alteration zones. Dark green and greenish-gray skarns are medium- to coarse-grained and composed of tremolite, diopside, scapolite, and potassium feldspar, criss-crossed by calcite and quartz-feldspathic veins (Fig. 6C). This interaction is sometimes evidenced by the formation of centimeter-sized blue apatite crystals disseminated in the diopsidite associated with pegmatites.
Petrographically, calcsilicate rocks show polygonal to decussate granoblastic textures, mainly in tremolite-diopside-granofels, along with occasional porphyroblastic and mylonitic textures in calcsilicate gneisses. Figure 6D presents the gneissic banding formed by pyroxene- and amphibole-rich layers alternated with feldspar- and quartz-rich layers. These rocks are classified as calcsilicate gneisses, diopsidites, and diopsidites with microcline.

Diopside in calcsilicate gneisses comprises about $40 \%$ of the rock volume and forms predominantly hypidiomorphic crystals along with some idiomorphic ones. They display limited to moderate degrees of hydrothermal alteration. Diopside is altered to hornblende at the rims (Fig. 6E).

Feldspar crystals are subdiomorphic and present moderate to high degrees of hydrothermal alteration, mostly to 

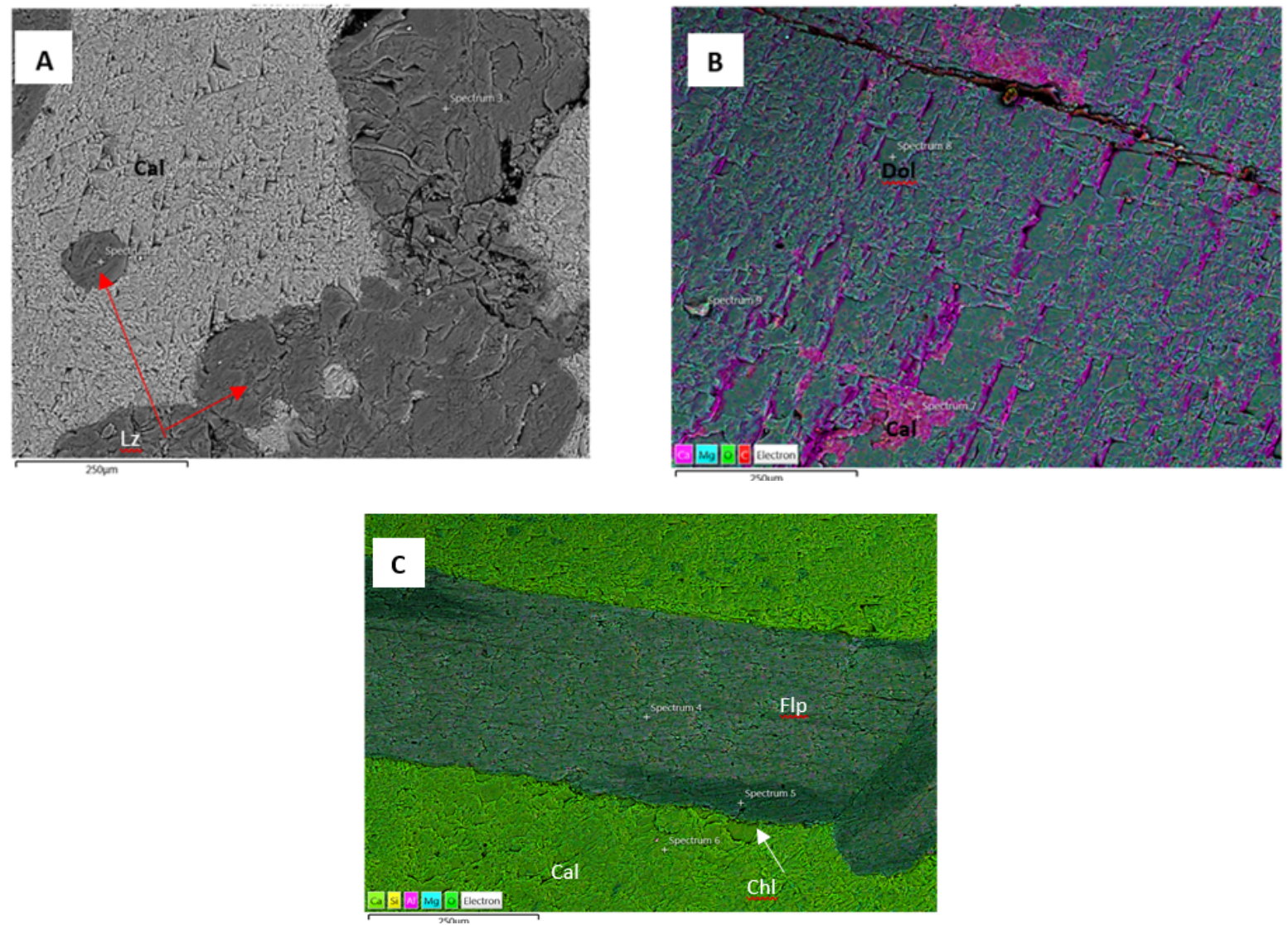

Figure 5. Scanning electron microscopy (SEM) image of Group 1 marbles (MM-TR-302 and 386A samples). (A) Backscattered electron image of calcite and lizardite. (B) Energy-dispersive spectrometry (EDS) image of dolomite interspersed with calcite. (C) EDS image of phlogopite, chlorite, and calcite.

epidote (saussuritization) and sericitization. Plagioclases and K-feldspar (microcline) could be distinguished by the characteristic twinning in some samples. When this aspect is absent, they are defined as feldspar. The Michel Levi method indicates a labradorite composition for plagioclase, confirming the works of Oliveira (1976) and Polleto (2014). The presence of detrital zircon is evidenced in Figure 6F.

\section{Apatite in marbles and calcsilicates}

Apatite makes up about 5 to 10 vol.\% of the total rock volume in calcsilicate and marble sequences of the Tanque Novo-Ipirá Complex. It is present in both marble groups and most commonly occurs as colorless, white to greyish subdiomorphic to xenomorphic prismatic inclusions in calcite (Fig. 7A). More rarely, they occur as idiomorphic crystals in straight contact with calcite and interstitial quartz (Fig. 7B). In calcsilicate rocks, apatite forms subdiomorphic to idiomorphic crystals with a prismatic habit oriented according to the foliation. They are associated with feldspar, hornblende, and diopside separated by straight to curved contacts (Figs. 7C and 7D). The XRD analysis shows that fluorapatite is associated with calcite and diopside in the Group 1 marble and in diopsidites, respectively (Suppls. 2 and 3).

\section{Metapsammites}

Metapsammites occur in the south and south-central regions of the study area, between the Bonfim de Ipirá and
Ipirá districts. The best preserved metapsammite outcrops are found on mountain tops, such as Serra do Camisão, where they are associated with the main phosphate mineralizations in this region. Their quartz contents vary from 40 to 60 vol.\%. Other associated minerals include feldspar, garnet, diopside, biotite, sericite, and zircon. These rocks have porphyroblastic garnet crystal and granular granoblastic textures (Figs. 8A-8C).

\section{Graphite schists}

Graphite schists occur in contact with metapsammite and marble in bodies of reduced widths but with extensive continuity ( $2.3 \mathrm{~km}, \mathrm{~N}-\mathrm{S}$ direction) that were not mapped on the 1:100,000 scale. Brown clay-rich sands and residual soil characterize the weathering profile. Two samples were petrographically described: graphite-feldspar schist sample, located north of Bonfim-Ipirá, and schist with graphite, dolomite, sericite, and quartz, associated with possible organic structures located south of Bonfim do Ipirá (Figs. 9A and 9B).

\section{RESULTS}

Analytical results are listed in Tables 1 and 2. Ce, Pr, Eu, and $\mathrm{Gd}$ anomalies were calculated according to the method of Bau and Dulski (1996): $\mathrm{Ce} / \mathrm{Ce}_{\mathrm{SN}}^{*}\left[\mathrm{Ce}_{\mathrm{SN}} /\left(0.5 \mathrm{Pr}_{\mathrm{SN}}+0.5\right.\right.$ $\left.\left.\mathrm{La}_{\mathrm{SN}}\right)\right], \operatorname{Pr} / \mathrm{Pr}_{\mathrm{SN}}^{*}\left[\mathrm{Pr}_{\mathrm{SN}} /\left(0.5 \mathrm{Ce}_{\mathrm{SN}}+0.5 \mathrm{Nd}_{\mathrm{SN}}\right)\right], \mathrm{Eu} / \mathrm{Eu}_{\mathrm{SN}}{ }$ $\left[\mathrm{Eu}_{\mathrm{SN}} /\left(0.67 \mathrm{Sm}_{\mathrm{SN}}+0.33 \mathrm{~Tb}_{\mathrm{SN}}\right)\right]$ and $\mathrm{Gd} / \mathrm{Gd}_{\mathrm{SN}}^{*}\left[\mathrm{Gd}_{\mathrm{SN}} /(0.33\right.$ $\left.\left.\mathrm{Sm}_{\mathrm{SN}}+0.67 \mathrm{~Tb}_{\mathrm{SN}}\right)\right]$. 

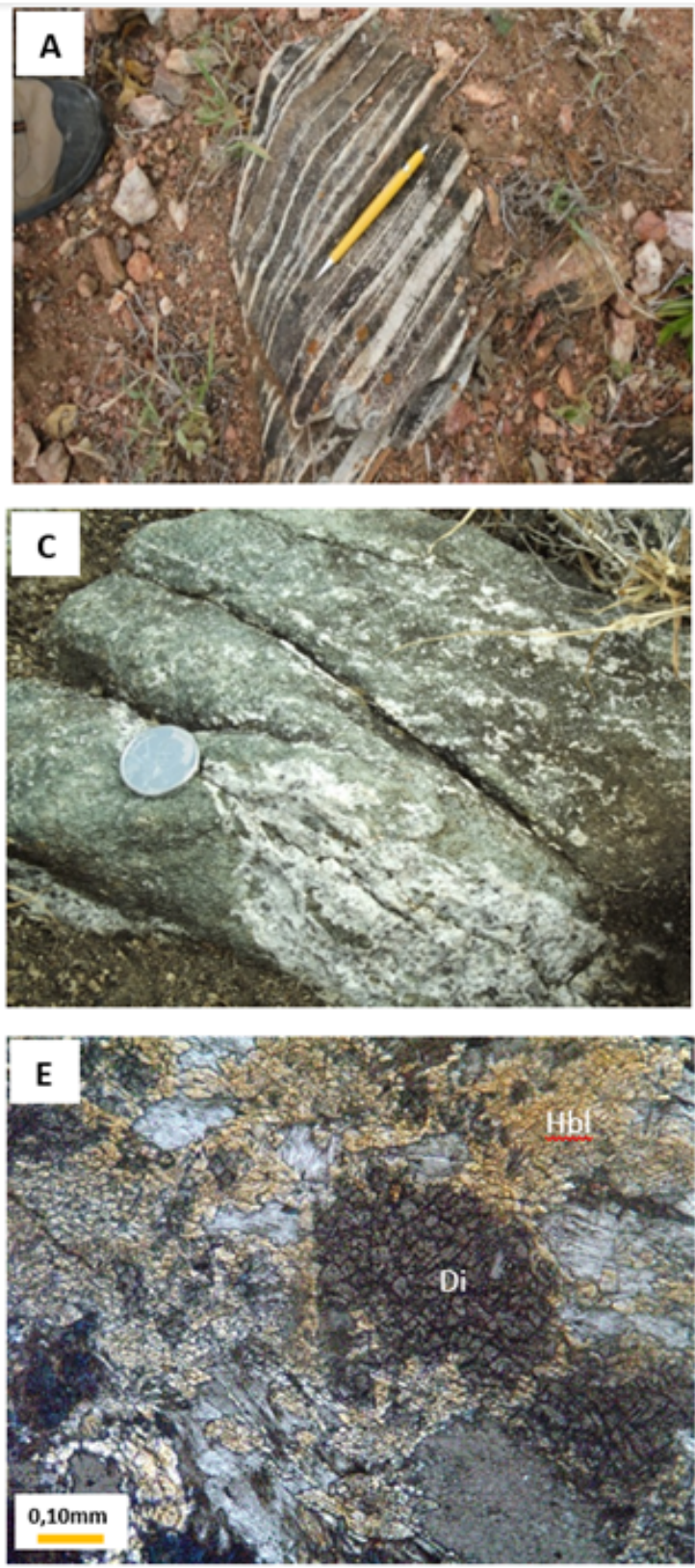
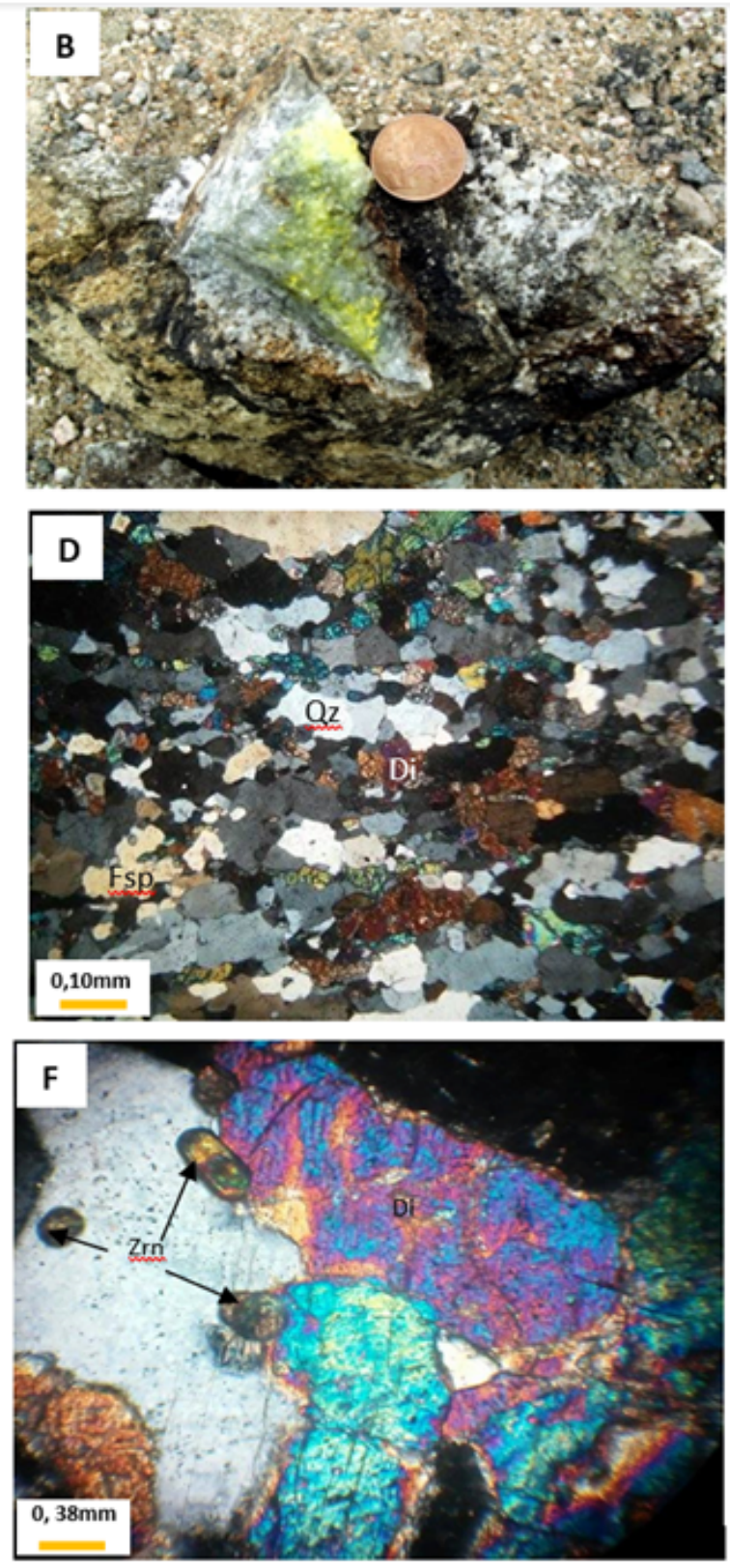

Figure 6. (A) Detail of compositional bandings showing quartz bands parallel to foliation. (B) Positive colorimetric test for phosphorus in a calcsilicate rock. (C) Outcrop of a calcsilicate rock in a contact zone (skarn) near the Gavião district showing injections/remobilization of carbonate veins. (D) Stretched quartz (Qz) and feldspar (Fsp) crystals in bands and diopside (Di). (E) Reaction corona of hornblende (Hbl) around diopside (Di). (F) Idiomorphic and subdiomorphic zircon ( $\mathrm{Znn}$ ) crystals in diopsidite.

\section{Major and trace element geochemistry}

The $\mathrm{SiO}_{2}$ concentration in marbles ranges from 9.5 to $15.92 \mathrm{wt} . \%$ in Group 1 and 14 to $21 \mathrm{wt} . \%$ in Group 2. The average $\mathrm{MgO}$ content is 15.7 wt.\% in Group 1 and 1.3 wt.\% in Group 2, whereas the average abundance of $\mathrm{CaO}$ in the groups is 33.5 and 40.16 wt. $\%$, respectively. The $\mathrm{Al}_{2} \mathrm{O}_{3}$ concentrations in Group 1 marbles range from 0.52 to $1.44 \mathrm{wt}$.\%, whereas rocks of Group 2 present 4.38 to 7.14 wt. $\% \mathrm{Al}_{2} \mathrm{O}_{3}$.

In calcsilicate rocks, the $\mathrm{SiO}_{2}$ concentration ranges from 47 to $68 \mathrm{wt}$.\%, with an average of $57.8 \mathrm{wt} . \%$. $\mathrm{CaO}$ and $\mathrm{MgO}$ contents are highly variable: the $\mathrm{CaO}$ content averages 16.23 wt.\%, ranging from 2.2 to $24.62 \mathrm{wt} . \%$, whereas $\mathrm{MgO}$ concentrations range between 1.2 and $20.83 \mathrm{wt}$. , with an average of $11.2 \mathrm{wt} . \%$. The average $\mathrm{Al}_{2} \mathrm{O}_{3}$ and $\mathrm{K}_{2} \mathrm{O}$ contents are 6.74 and $2.10 \mathrm{wt} . \%$, respectively, and the $\mathrm{K}_{2} \mathrm{O}$ content ranges between 0.05 and 7.48 wt.\%.
Samples from the Group 1 plot in the field of calcitic-dolomitic to dolomitic marbles and from Group 2 are classified as calcsilicate marbles (Fig. 10A).

The $\mathrm{P}_{2} \mathrm{O}_{5}$ concentration in calcsilicate rocks averages $0.13 \mathrm{wt} . \%$, but anomalously high contents of 2.03 and $3.20 \mathrm{wt}$.\% were measured in MM-TR-389B and MM-TR-55B samples, respectively.

In Group 1 marbles, the $\mathrm{P}_{2} \mathrm{O}_{5}$ content averages $0.86 \mathrm{wt}$.\% (0.04 to $2.33 \mathrm{wt} . \%$ ), and the highest concentrations are found in MM-TR-297, MM-TR-302, and KP-49 samples (0.99, 1.58, and $2.33 \mathrm{wt}$ \%, respectively). Marbles of Group 2 present lower $\mathrm{P}_{2} \mathrm{O}_{5}$ concentrations -0.14 to 0.19 wt.\% (Fig. 10B).

\section{Rare Earth Elements and Yttrium (REEY) Behavior}

Marbles of Group 1 have $\Sigma$ REE ranging from 7.87 to 45.88 ppm (average 23.3). Marbles of Group 2 have higher 

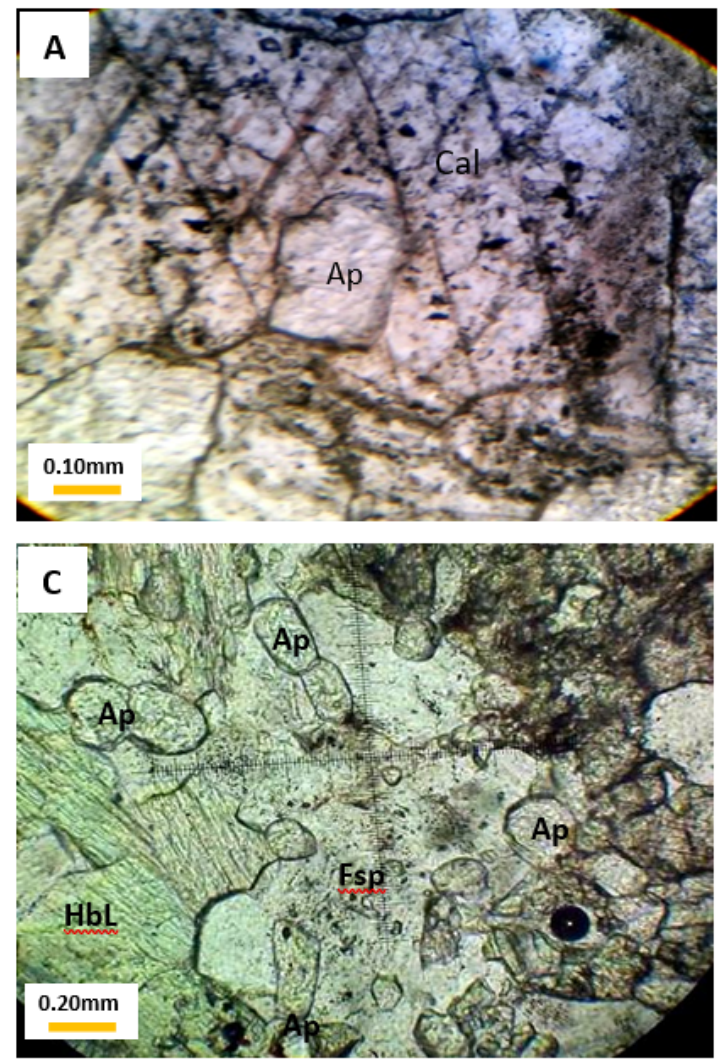
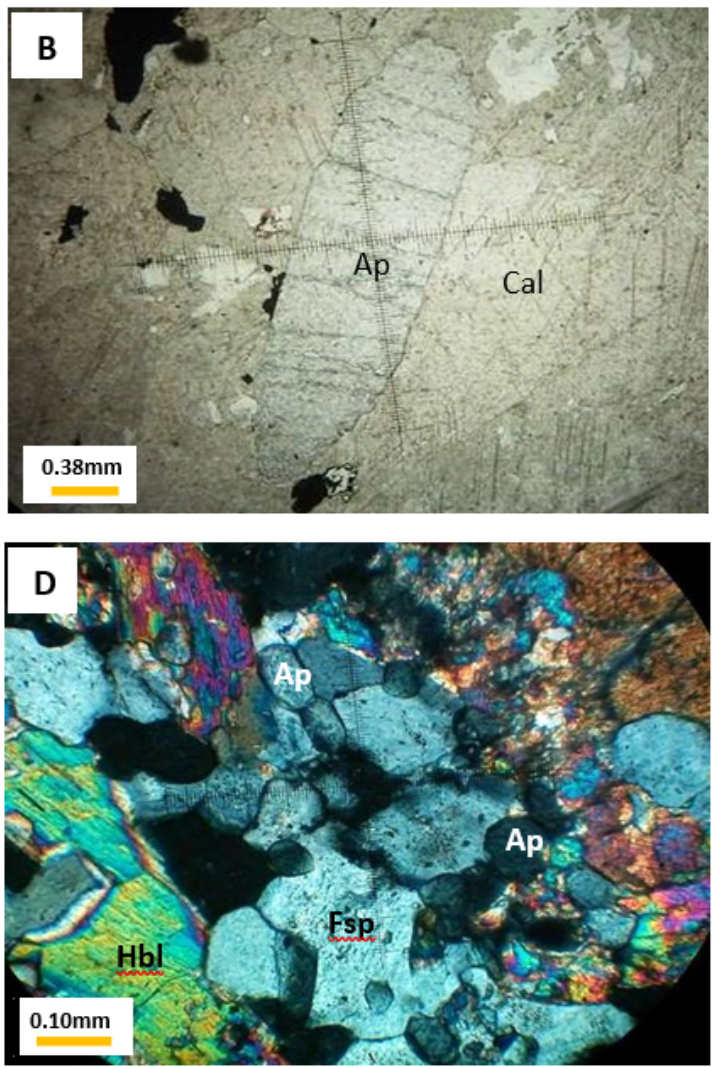

Figure 7. (A) Apatite (Ap) inclusions in calcite (Cal); (B) Idiomorphic apatite in marble; (C \& D) Apatite crystals oriented in a calcsilicate rock (C: PPL; D: XPL). PPL: plane-polarized light; XPL: cross-polarized light.
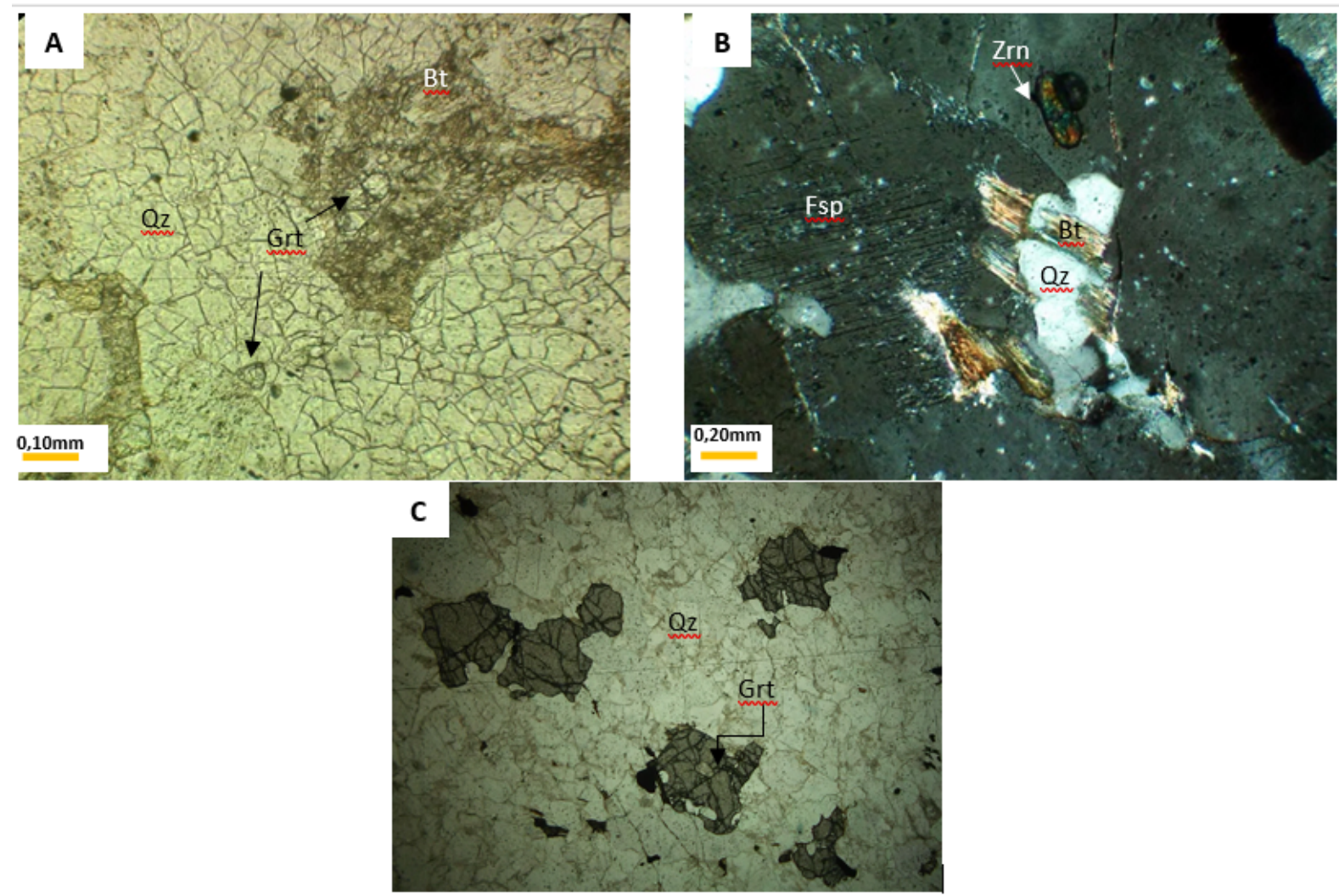

Figure 8. (A) Metapsammite with granular granoblastic texture containing garnet, feldspar, and sericite. (B) Inclusion of biotite in sericitized feldspar alongside idiomorphic zircon inclusions. (C) Metapsammite with porphyroblastic texture containing garnet and quartz. 

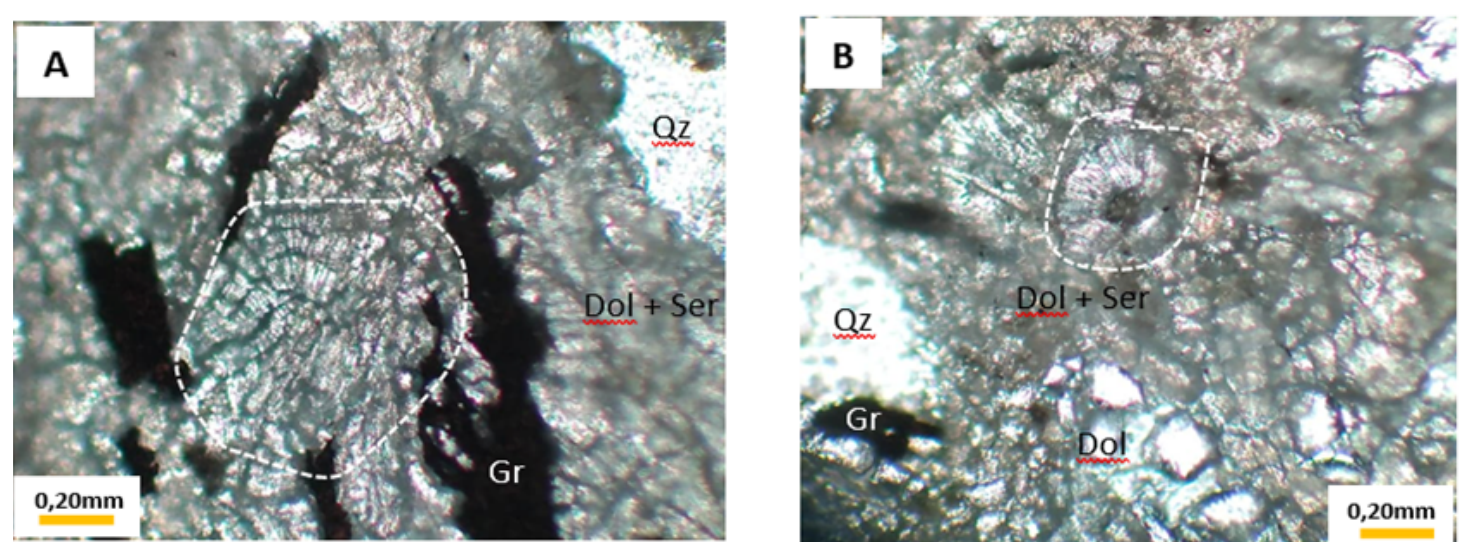

Figure 9. (A) Graphite associated with inferred organic structures (dashed line), dolomite, and quartz. (B) Dolomite associated with organic structures and quartz in a sericitic matrix.

$\Sigma$ REE contents (79.92 and $59.36 \mathrm{ppm})$. Calcsilicate rocks show $\Sigma$ REE contents of 22.10-323.42 ppm (average 85.87). Y contents range between 28 and $40 \mathrm{ppm}$ in marbles of Group 1 and between 26 and 27 ppm in marbles of Group 2.

Most rocks have flat, REE-depleted patterns with respect to PAAS, negative Ce anomalies, variable but generally positive Eu anomalies, and positive $Y$ anomalies. REE-normalized patterns of Group 2 marbles are flatter and closer to the PAAS composition. Marbles exhibit a small enrichment in light REE (LREE) compared to heavy REE (HREE), as evidenced by $\mathrm{Pr} / \mathrm{Yb}_{\mathrm{SN}}$ ratios, ranging from 0.60 to 2.73 in Group 1 marbles and around 1.3 in Group 2 marbles. LREE enrichment is most prominent in calcsilicate rocks $\left(\mathrm{Pr} / \mathrm{Yb}_{\mathrm{SN}} 0.80-3.81\right)$.

Most samples show negative $\mathrm{Ce}$ anomalies. Marbles of Group 1 have $\mathrm{Ce} / \mathrm{Ce}^{*}$ values of $0.12-0.57$, except for the TR-386 sample (1.91), whereas marbles of Group 2 show $\mathrm{Ce} / \mathrm{Ce}^{*}$ values of 0.88 and 0.86 . Most calcsilicate samples $(n=24 / 29)$ present negative Ce anomalies $\left(\mathrm{Ce} / \mathrm{Ce}^{*} 0.46-\right.$ $0.99)$, excluding 5 samples in which $\mathrm{Ce} / \mathrm{Ce}^{*}$ varies from 1.01 to 1.27 . The measured Eu anomalies are highly variable: Group 1 marbles show $\mathrm{Eu} / \mathrm{Eu}^{*}$ values of 0.92 to 1.82 , while these values range between 0.98 and 1.08 in Group 2 marbles and between 0.45 and 1.56 in calcsilicate rocks. Calcsilicate rocks have $\mathrm{Y} / \mathrm{Ho}$ ratios between 23.4 and 37.4. Group 1 marbles display $\mathrm{Gd} / \mathrm{Gd}^{*}$ values of $1.08-1.36$, whereas these ratios vary from 1.10 to 1.15 in Group 2 and from 0.94 to 1.94 in calcsilicate rocks.

\section{Geochronology}

Zircon crystals extracted from the calcsilicate rock sample (MM-TR-26) are pale brown, light pink, and colorless, with a subdiomorphic to idiomorphic prismatic habit. Twenty spots in 19 zircons (Tab. 3 ) yielded 2 concordant ages of $2595 \pm 18 \mathrm{Ma}$, placed in the crystal core, whereas the rims gave an age of $2082 \pm 14 \mathrm{Ma}$, which was interpreted as a late Paleoproterozoic metamorphic event (Fig. 11).

The ${ }^{207} \mathrm{~Pb} /{ }^{206} \mathrm{~Pb}$ age of the oldest zircon is $2736 \mathrm{Ma}$, registered in only one crystal. The sample has a higher frequency of Paleoproterozoic crystals from 2453 to $2128 \mathrm{Ma}$ and older Neoarchean populations aged between 2736 and $2573 \mathrm{Ma}$. The youngest zircon found is $2128 \mathrm{Ma}$, not the age of the most frequent Paleoproterozoic population, but it marks the maximum deposition limit of the metasedimentary package. Zircons have U (53-374 ppm) and Th (20-374 ppm) content and $\mathrm{Th} / \mathrm{U}$ ratios varying between $0.21-1.88 \mathrm{ppm}$.

\section{DISCUSSION}

The intense deformation and metamorphism hinder the reconstruction of the metasedimentary succession of the Tanque Novo-Ipirá Complex. Primary sedimentary structures were obliterated, making it difficult to interpret the depositional environment, but correlations between elements and geochemical patterns, especially REEY signatures, provide information about their origin and possible paleoenvironmental conditions during and after sedimentation.

The mineral association of metasediments reflects two mineral parageneses: prograde and retrograde assemblage. The prograde mineral assemblage consists of olivine + diopside + garnet + calcite, while the retrograde assemblage comprises serpentine + tremolite + microcline + biotite + hornblende + talc + sericite. According to Ribeiro (2016) and considering that the metamorphism was essentially anhydrous and developed under conditions of high $\mathrm{CO}_{2}$ fugacity, the association of forsterite + calcite, responsible for the progressive paragenesis, was derived from the $\mathrm{Di}+3 \mathrm{Dol}=4 \mathrm{Cal}+\mathrm{Fo}+2 \mathrm{CO}_{2}$ reaction (Winkler 1979). The variation of equilibrium conditions for this reaction according to different values of temperature and $\mathrm{CO}_{2}$ fugacity suggests a pressure range of 4 to $7 \mathrm{kbar}$ and temperature conditions between 710 and $810^{\circ} \mathrm{C}$ (Berman 1991), respectively, indicating that progressive metamorphism has reached transitional amphibolite-granulite metamorphic conditions.

Olivine serpentinization should have occurred at $500^{\circ} \mathrm{C}$ under low $\mathrm{XCO}_{2}$ conditions (about 5\%), which represents the stability field of this mineral (Evans 2010). Serpentine talcification requires greater $\mathrm{CO}_{2}$ fugacity and would have occurred at temperatures of $350-450^{\circ} \mathrm{C}$ (Winkler 1979).

Although REEY are often relatively immobile, they can be mobilized during metamorphic processes, especially during metasomatic events (Bau 1991, 1993, 1999, Borisov et al. 2018). However, REEY patterns experience limited change 
Braz. J. Geol. (2021), 51(3): e20190137

Table 1. Major, trace, and rare earth element concentrations in the analyzed marble (MRM) samples.

\begin{tabular}{|c|c|c|c|c|c|c|c|c|}
\hline \multirow[b]{2}{*}{ Sample } & \multicolumn{2}{|l|}{ Group 1} & \multirow[b]{2}{*}{ MM-TR-297 } & \multirow[b]{2}{*}{ MM-TR-302 } & \multirow[b]{2}{*}{ MM-KP-49 } & \multicolumn{3}{|c|}{ Group 2} \\
\hline & MM-TR-69A & MM-TR-275 & & & & MM-TR-56A & MM-TR-293 & MM-TR-299 \\
\hline & MRM & MRM & MRM & MRM & MRM & MRM & MRM & MRM \\
\hline $\mathrm{SiO}_{2}$ (wt.\%) & 10.95 & 11.13 & 12.12 & 11.01 & 12.99 & 9.50 & 21.21 & 14.05 \\
\hline $\mathrm{TiO}_{2}$ & $<0.01$ & 0.06 & 0.05 & 0.08 & 0.12 & 0.03 & 0.31 & 0.09 \\
\hline $\mathrm{Al}_{2} \mathrm{O}_{3}$ & 0.65 & 1.44 & 0.67 & 1.20 & 1.00 & 1.12 & 7.14 & 4.38 \\
\hline $\mathrm{Fe}_{2} \mathrm{O}_{3(t)}$ & 0.48 & 1.24 & 1.24 & 1.36 & 0.96 & 0.85 & 3.85 & 1.54 \\
\hline $\mathrm{MnO}$ & 0.09 & 0.07 & $<0.01$ & 0.14 & 0.04 & 0.07 & 0.08 & 0.07 \\
\hline $\mathrm{MgO}$ & 16.88 & 18.04 & 13.95 & 15.00 & 17.65 & 12.38 & 1.84 & 0.79 \\
\hline $\mathrm{CaO}$ & 34.93 & 28.33 & 32.10 & 36.52 & 29.58 & 38.21 & 39.93 & 40.39 \\
\hline $\mathrm{K}_{2} \mathrm{O}$ & 0.04 & 0.07 & 0.08 & 0.11 & 0.11 & 0.05 & 2.40 & 1.38 \\
\hline $\mathrm{Na}_{2} \mathrm{O}$ & $<0.01$ & $<0.01$ & $<0.01$ & 0.11 & 0.12 & 0.02 & 0.20 & 0.07 \\
\hline $\mathrm{P}_{2} \mathrm{O}_{5}$ & 0.10 & 0.28 & 0.99 & 1.58 & 2.33 & 0.72 & 0.14 & 0.19 \\
\hline LOI & 35.80 & 34.65 & 34.44 & 34.43 & 33.30 & 36.42 & 27.33 & 32.89 \\
\hline Sum & 99.92 & 95.31 & 95.64 & 101.54 & 98.20 & 99.37 & 104.43 & 95.84 \\
\hline $\mathrm{Ba}(\mathrm{ppm})$ & 130.00 & 9.00 & 9.00 & 333.00 & 33.00 & $1,814.00$ & 150.00 & 133.00 \\
\hline $\mathrm{Hf}$ & $<0.05$ & 0.52 & 0.94 & 0.21 & 1.32 & $<0.05$ & 2.37 & 1.18 \\
\hline $\mathrm{Rb}$ & 1.60 & 0.40 & 0.40 & 0.40 & N.A. & 1.30 & 63.30 & 48.80 \\
\hline Ga & 0.70 & 3.10 & 2.30 & 2.90 & 1.70 & 1.70 & 10.20 & 6.70 \\
\hline $\mathrm{Zr}$ & 9.00 & 22.00 & 28.00 & 9.00 & 72.00 & 20.00 & 87.00 & 76.00 \\
\hline $\mathrm{Sr}$ & 70.00 & 32.00 & 88.00 & 66.00 & 46.00 & 30.00 & 510.00 & 852.00 \\
\hline $\mathrm{Cr}$ & 4.00 & 2.00 & 3.00 & 13.00 & 6.00 & 5.00 & 41.00 & 8.00 \\
\hline $\mathrm{Ni}$ & 7.00 & 14.00 & 10.00 & 15.00 & 18.00 & 12.00 & 13.00 & 3.00 \\
\hline Co & 4.00 & $<3$ & $<3$ & 4.00 & 2.50 & 4.00 & 3.00 & $<3$ \\
\hline V & 7.00 & 3.00 & 5.00 & 13.00 & $<5$ & 8.00 & 25.00 & 10.00 \\
\hline $\mathrm{U}$ & 1.39 & 0.11 & 2.44 & 0.32 & 0.24 & 0.46 & 2.16 & 3.87 \\
\hline Y & 12.68 & 3.09 & 11.95 & 17.98 & 3.58 & 5.10 & 11.66 & 9.01 \\
\hline $\mathrm{La}$ & 39.00 & 16.30 & 19.60 & 12.00 & 9.70 & 51.90 & 29.50 & 22.50 \\
\hline $\mathrm{Ce}$ & 10.50 & 9.80 & 15.20 & 11.90 & 8.00 & 7.10 & 46.00 & 33.90 \\
\hline $\operatorname{Pr}$ & 5.13 & 1.00 & 1.80 & 1.51 & 0.86 & 1.23 & 4.74 & 3.53 \\
\hline $\mathrm{Nd}$ & 19.70 & 4.00 & 7.80 & 6.50 & 3.20 & 3.10 & 17.30 & 12.90 \\
\hline Sm & 3.00 & 0.60 & 1.80 & 1.40 & 0.60 & 0.50 & 2.80 & 2.20 \\
\hline $\mathrm{Eu}$ & 0.63 & 0.14 & 0.35 & 0.31 & 0.14 & 0.22 & 0.58 & 0.42 \\
\hline Gd & 2.61 & 0.74 & 2.06 & 1.90 & 0.55 & 0.71 & 2.67 & 2.02 \\
\hline $\mathrm{Tb}$ & 0.41 & 0.11 & 0.31 & 0.29 & 0.08 & 0.12 & 0.37 & 0.30 \\
\hline Dy & 1.81 & 0.56 & 1.85 & 1.98 & 0.48 & 0.58 & 2.12 & 1.63 \\
\hline Ho & 0.38 & 0.11 & 0.41 & 0.45 & 0.10 & 0.15 & 0.45 & 0.33 \\
\hline $\mathrm{Er}$ & 0.91 & 0.32 & 1.25 & 1.26 & 0.27 & 0.35 & 1.33 & 0.98 \\
\hline $\operatorname{Tm}$ & 0.12 & 0.05 & 0.16 & 0.17 & 0.05 & 0.06 & 0.18 & 0.13 \\
\hline $\mathrm{Yb}$ & 0.60 & 0.20 & 0.90 & 0.80 & 0.20 & 0.30 & 1.20 & 0.90 \\
\hline $\mathrm{Lu}$ & 0.08 & 0.05 & 0.14 & 0.11 & 0.05 & 0.06 & 0.18 & 0.12 \\
\hline$\Sigma \mathrm{REE}$ & 45.88 & 17.68 & 34.03 & 28.58 & 14.58 & 14.48 & 79.92 & 59.36 \\
\hline$\Sigma$ LREE & 77.96 & 31.84 & 46.55 & 33.62 & 22.50 & 64.05 & 100.92 & 75.45 \\
\hline$\Sigma$ HREE & 6.92 & 2.14 & 7.08 & 6.96 & 1.78 & 2.33 & 8.50 & 6.41 \\
\hline $\mathrm{Ce} / \mathrm{Ce}^{*}$ & 0.16 & 0.46 & 0.53 & 0.62 & 0.57 & 0.12 & 0.88 & 0.86 \\
\hline $\operatorname{Pr} / \operatorname{Pr}^{*}$ & 1.63 & 0.94 & 0.97 & 1.00 & 1.00 & 1.54 & 0.99 & 0.99 \\
\hline $\mathrm{Y} / \mathrm{Y}^{*}$ & 1.22 & 0.99 & 1.09 & 1.52 & 1.30 & 1.37 & 0.95 & 0.98 \\
\hline Y/Ho & 33.37 & 28.09 & 29.15 & 39.96 & 35.80 & 34.00 & 25.91 & 27.30 \\
\hline $\mathrm{Eu} / \mathrm{Sm}$ & 0.21 & 0.23 & 0.19 & 0.22 & 0.23 & 0.44 & 0.21 & 0.19 \\
\hline $\mathrm{Ba} / \mathrm{Nd}$ & 6.60 & 2.25 & 1.15 & 51.23 & 10.31 & 585.16 & 8.67 & 10.31 \\
\hline $\mathrm{Eu} / \mathrm{Eu}^{*}$ & 1.09 & 1.09 & 0.93 & 0.98 & 1.22 & 1.83 & 1.08 & 0.99 \\
\hline $\mathrm{Gd} / \mathrm{Gd}^{*}$ & 1.04 & 1.33 & 1.26 & 1.39 & 1.11 & 1.37 & 1.16 & 1.10 \\
\hline $\mathrm{MgO}+\mathrm{CaO}$ & 51.81 & 46.37 & 46.05 & 51.52 & 47.23 & 50.59 & 41.77 & 41.18 \\
\hline $\mathrm{Dy} / \mathrm{Sm}_{\mathrm{N}}$ & 0.72 & 1.11 & 1.22 & 1.68 & 0.95 & 1.38 & 0.90 & 0.88 \\
\hline $\operatorname{Pr} / \mathrm{Sm}_{\mathrm{N}}$ & 1.07 & 1.05 & 0.63 & 0.68 & 0.90 & 1.55 & 1.06 & 1.01 \\
\hline$\Sigma$ REEY-La & 5.76 & 1.66 & 4.84 & 4.78 & 1.49 & 1.90 & 6.81 & 5.09 \\
\hline $\mathrm{Pr} / \mathrm{Yb}_{\mathrm{N}}$ & 2.73 & 1.60 & 0.64 & 0.60 & 1.37 & 1.31 & 1.26 & 1.25 \\
\hline $\mathrm{Sm} / \mathrm{Yb}_{\mathrm{N}}$ & 2.54 & 1.52 & 1.02 & 0.89 & 1.52 & 1.22 & 1.19 & 1.24 \\
\hline $\mathrm{Sm} / \operatorname{Pr}_{\mathrm{N}}$ & 0.93 & 0.95 & 1.59 & 1.48 & 1.11 & 0.94 & 0.94 & 0.99 \\
\hline
\end{tabular}

REE: rare earth elements; LREE: light REE; HREE: heavy REE; REEY: REE and yttrium; N.A.: not analyzed. 


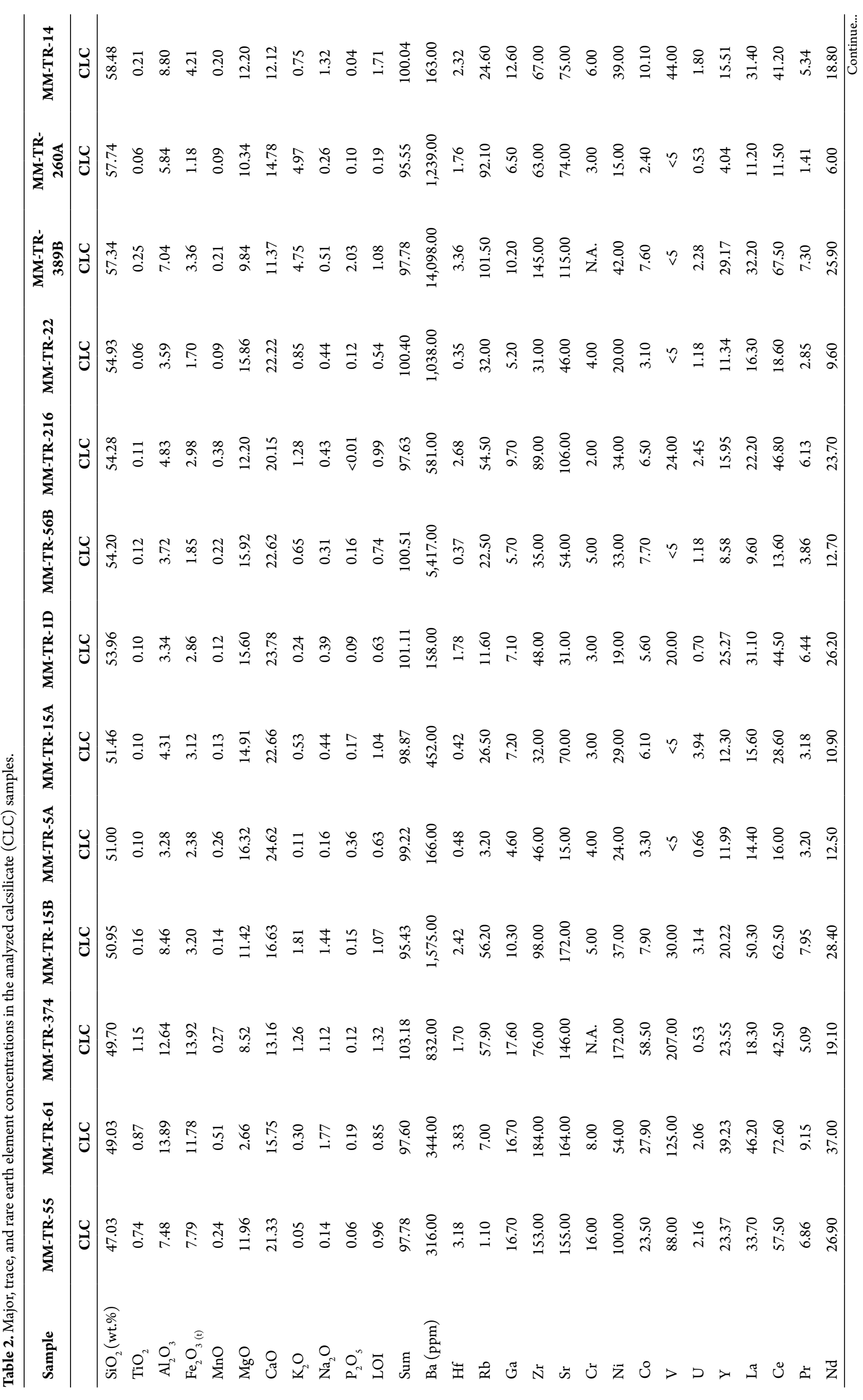




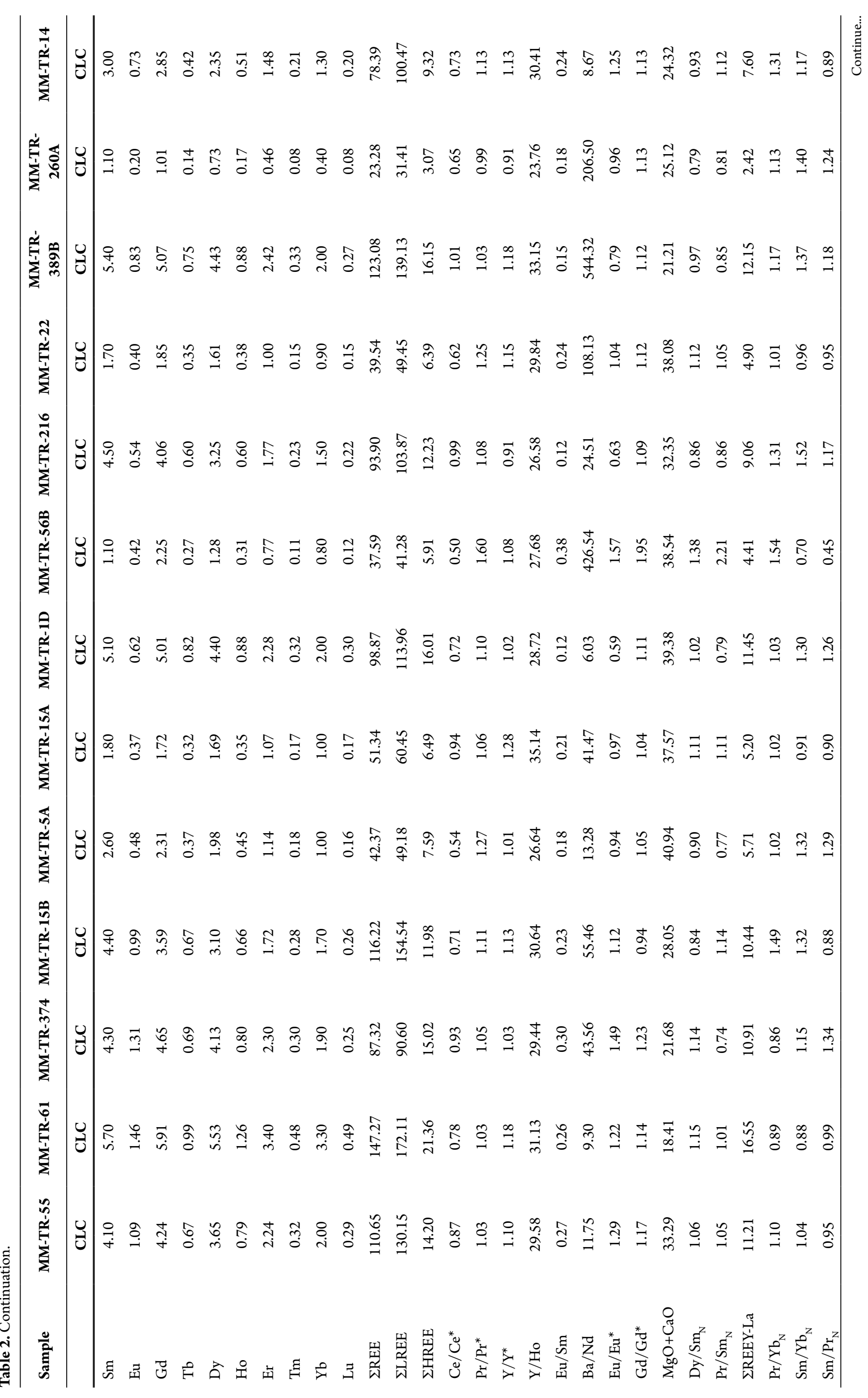




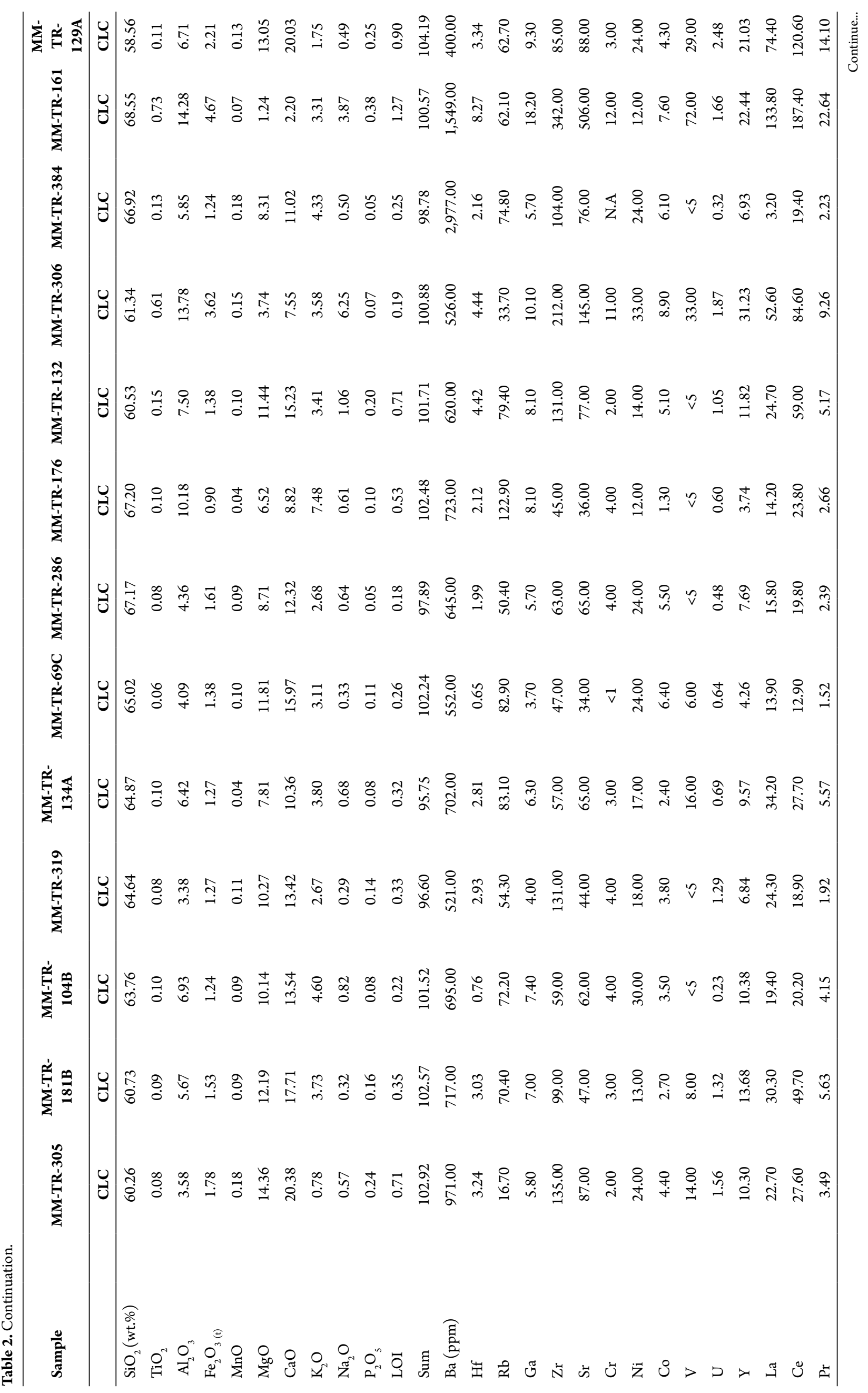




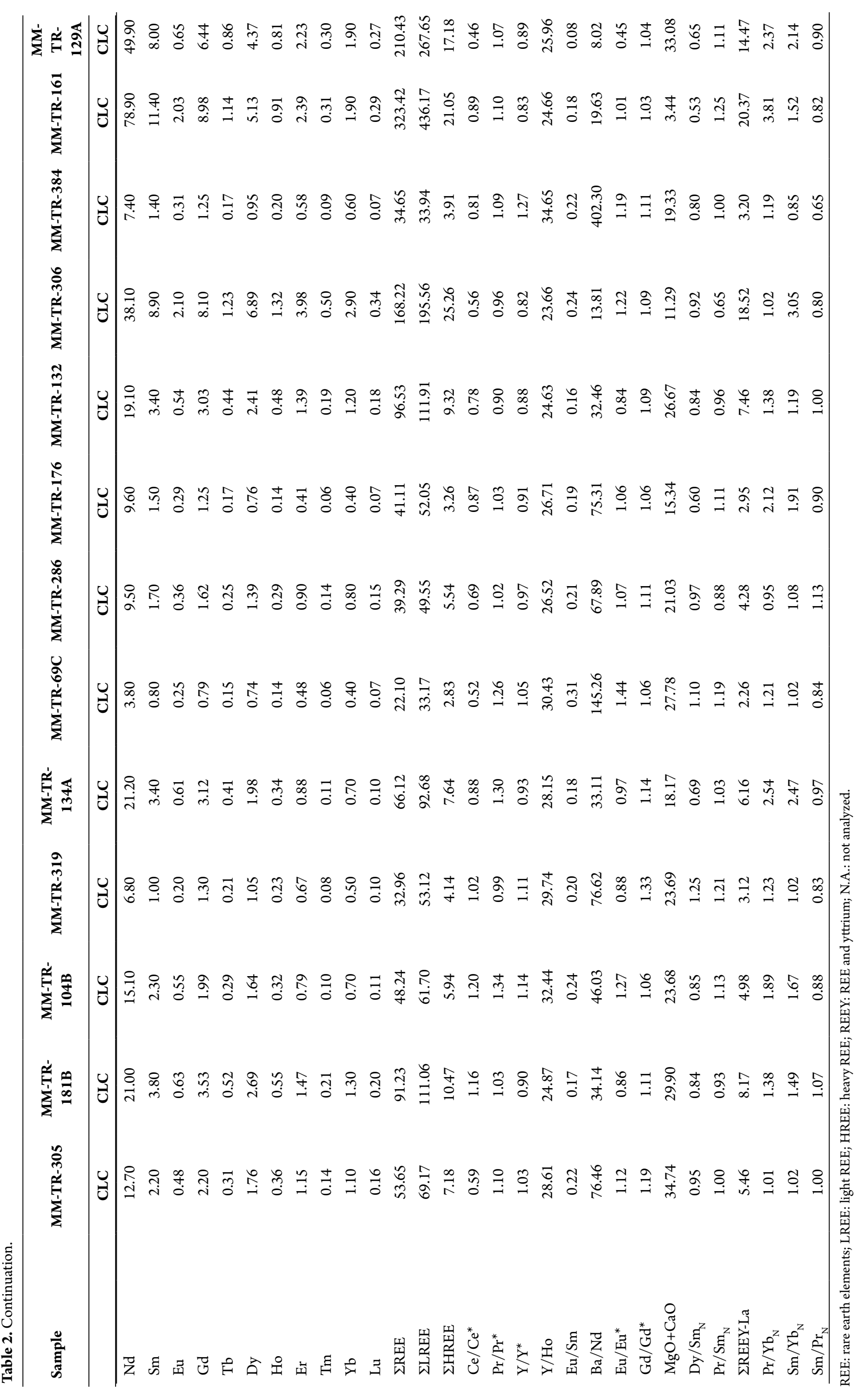



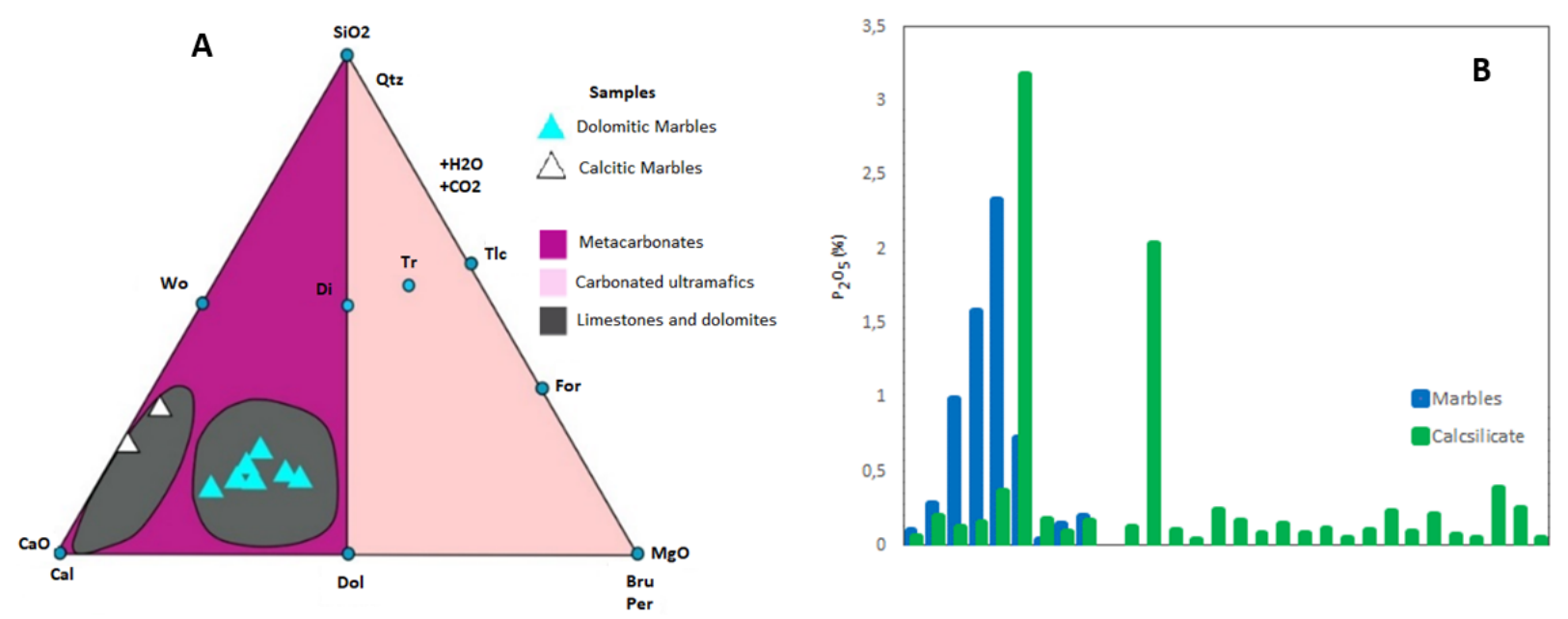

Figure 10. (A) CMS-HC system $\left(\mathrm{CaO}-\mathrm{MgO}-\mathrm{SiO}_{2}-\mathrm{H}_{2} \mathrm{O}-\mathrm{CO}_{2}\right)$ (Winter 2001) showing the dolomitic and calcitic marbles studied. (B) $\mathrm{P}_{2} \mathrm{O}_{5}$ (\%) content in the lithofacies.

Table 3. U-Pb isotope data in the MM-TR-26 calcsilicate sample.

\begin{tabular}{|c|c|c|c|c|c|c|c|c|c|c|c|c|c|}
\hline & & & & & & Age & & & & & & & Conc. \\
\hline & & ${ }^{206} \mathbf{P b} /{ }^{204} \mathbf{P b}$ & Th & $\mathbf{U}$ & $\mathbf{T h} / \mathbf{U}$ & $T_{206 / 238}$ & 1 sigma & $\mathbf{T}_{207 / 235}$ & 1 sigma & $T_{207 / 206}$ & 1 sigma & Location & $206 / 238$ \\
\hline Sample & Spot & & ppm & ppm & & & & & & & & & $207 / 235$ \\
\hline MM-TR-26 & 20 & 767.2 & 200 & 258 & 0.77 & 2,070 & 25 & 2,073 & 17 & 2,077 & 23 & Edge & 100 \\
\hline MM-TR-26 & 52 & 772.1 & 188 & 261 & 0.72 & 2,076 & 24 & 2,074 & 15 & 2,072 & 18 & Edge & 100 \\
\hline MM-TR-26 & 96 & 594.8 & 156 & 177 & 0.88 & 2,090 & 23 & 2,082 & 17 & 2,073 & 23 & Edge & 100 \\
\hline MM-TR-26 & 49 & 165.3 & 174 & 217 & 0.80 & 2,092 & 24 & 2,085 & 15 & 2,077 & 18 & Edge & 100 \\
\hline MM-TR-26 & 11 & 604.7 & 185 & 251 & 0.74 & 2,095 & 25 & 2,095 & 15 & 2,096 & 18 & Edge & 100 \\
\hline MM-TR-26 & 50 & 449.9 & 113 & 168 & 0.67 & 2,602 & 29 & 2,597 & 16 & 2,593 & 17 & Core & 100 \\
\hline MM-TR-26 & 57 & $70,947.9$ & 20 & 93 & 0.21 & 2,602 & 29 & 2,603 & 16 & 2,603 & 17 & Core & 100 \\
\hline MM-TR-26 & 80 & $1,220.3$ & 374 & 220 & 1.70 & 2,608 & 28 & 2,589 & 16 & 2,573 & 19 & Core & 101 \\
\hline MM-TR-26 & 79 & 293.1 & 258 & 137 & 1.88 & 2,135 & 24 & 2,131 & 15 & 2,128 & 19 & Intermediary & 100 \\
\hline MM-TR-26 & 68 & 76.8 & 138 & 163 & 0.85 & 2,156 & 24 & 2,141 & 15 & 2,127 & 19 & Edge & 101 \\
\hline MM-TR-26 & 18 & $149,124.1$ & 155 & 290 & 0.53 & 2,228 & 27 & 2,241 & 16 & 2,253 & 18 & Intermediary & 99 \\
\hline MM-TR-26 & 9 & 194.3 & 246 & 374 & 0.66 & 2,259 & 27 & 2,249 & 16 & 2,239 & 18 & Edge & 100 \\
\hline MM-TR-26 & 75 & 514.2 & 210 & 185 & 1.14 & 2,351 & 26 & 2,368 & 15 & 2,382 & 18 & Intermediary & 99 \\
\hline MM-TR-26 & 54 & $1,510.1$ & 279 & 199 & 1.41 & 2,408 & 27 & 2,418 & 16 & 2,426 & 17 & Intermediary & 100 \\
\hline MM-TR-26 & 53 & 438.8 & 54 & 53 & 1.03 & 2,417 & 27 & 2,414 & 17 & 2,412 & 21 & Intermediary & 100 \\
\hline MM-TR-26 & 67 & $142,191.1$ & 192 & 220 & 0.87 & 2,443 & 27 & 2,451 & 16 & 2,458 & 18 & Intermediary & 100 \\
\hline MM-TR-26 & 76 & $113,967.7$ & 127 & 176 & 0.72 & 2,449 & 27 & 2,451 & 16 & 2,453 & 18 & Intermediary & 100 \\
\hline MM-TR-26 & 33 & 114.7 & 60 & 170 & 0.35 & 2,642 & 29 & 2,645 & 16 & 2,647 & 17 & Core & 100 \\
\hline MM-TR-26 & 10 & 337.8 & 222 & 128 & 1.74 & 2,675 & 30 & 2,665 & 17 & 2,657 & 17 & Core & 100 \\
\hline MM-TR-26 & 39 & 179.2 & 142 & 129 & 1.10 & 2,699 & 30 & 2,720 & 16 & 2,736 & 17 & Core & 99 \\
\hline
\end{tabular}

Conc.: concordia.

during high-grade metamorphism under anhydrous conditions (Cullers et al. 1974, Bau 1991, 1993, Alexander et al. 2008 ), thus providing information about protoliths under these conditions.

Nevertheless, diagenetic and weathering processes can modify REEY patterns, and mixing with detrital sediments in the basin during deposition can also change the primary REEY signature in carbonate rocks (Shields and Stille 2001, Northdurft et al. 2004, Ling et al. 2013, Piper and Bau 2013, Zhu and Jiang 2017).

\section{Detrital contamination}

The mechanisms that may alter the REEY signature in marine chemical sediments, such as carbonates, are diagenesis, weathering, hydrothermalism, and detrital contamination. Terrigenous inputs contribute to the mixture of silicates and oxides within chemical sedimentary rocks (Northdurft et al. 2004, Ling et al. 2013, Piper and Bau 2013, Zhu and Jiang 2017). Terrigenous sediments typically have a higher content of REE and trace elements, such as $\mathrm{Zr}$, Th, and Hf, than carbonates (Taylor and McLennan 1985). According to Ling 

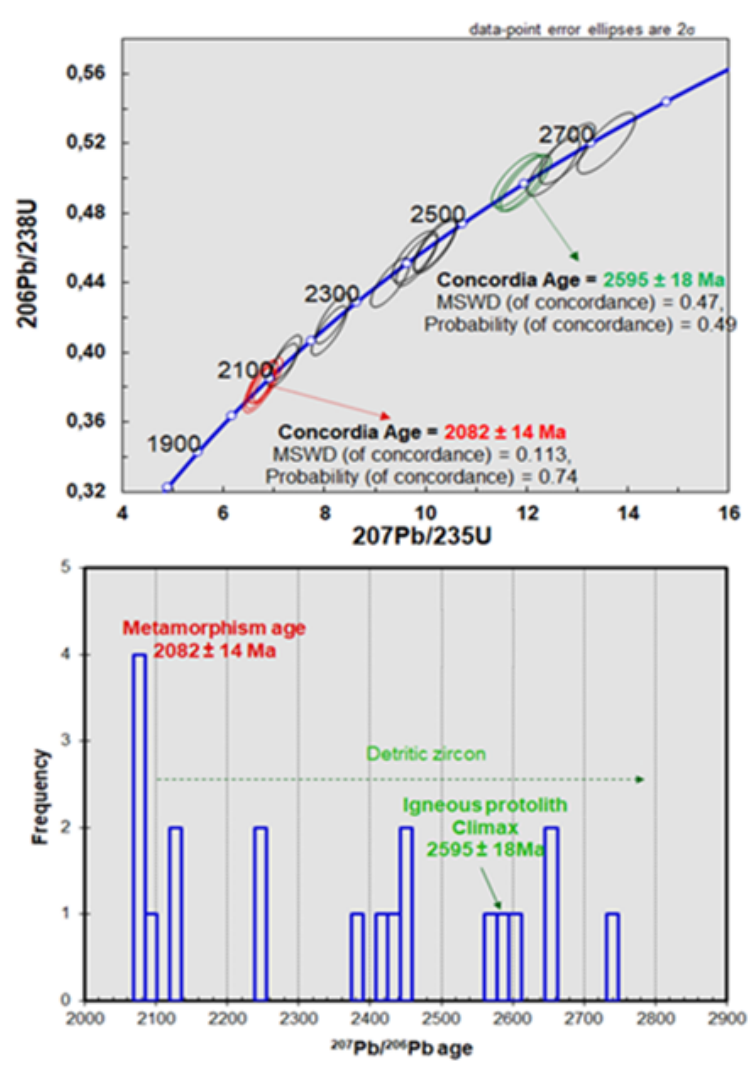
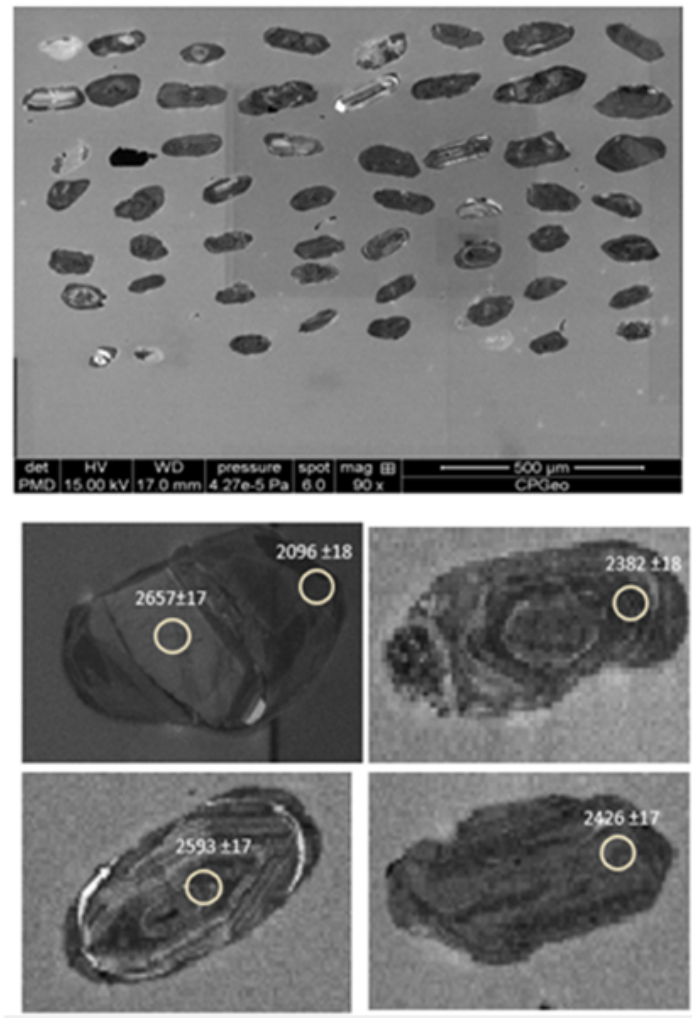

Figure 11. The left column shows the concordia diagram and the frequency distribution of the analyzed ages. The right column represents cathodoluminescence images of detrital zircons, with the location of the analyzed points and ${ }^{207} \mathrm{~Pb} /{ }^{206} \mathrm{~Pb}$ age. MSWD: mean squared weighted deviation.

et al. (2013) and Zhu and Jiang (2017), these REE can be partially transferred to carbonates during diagenesis. Depending on the degree of detrital contamination, the seawater signature may be partially or totally suppressed. The participation of silicates, oxides, and sulfides can be identified by the $\mathrm{Y} / \mathrm{Ho}$ ratio in relation to lithophile $(\mathrm{Zr}, \mathrm{Th}, \mathrm{Hf})$, chalcophile $(\mathrm{Pb}$, $\mathrm{Cu}$ ), and siderophile ( $\mathrm{Ni}, \mathrm{Co}, \mathrm{Cr}$ ) elements (Bolhar and Van Kranendonk 2007, Wang et al. 2018).

Y-Ho pairs are commonly assumed to be exclusively related to detrital components and are therefore used as a proxy for contamination of chemical sediments by detrital sediments in the basin (Bau and Dulski 1996, Bolhar et al. 2004).

Ho is removed through absorption by particulate matter in the marine system twice as fast as Y (Nozaki et al. 1997), generating positive $\mathrm{Y}$ anomalies, especially in open marine environments (Y/Ho 40-80), and smaller anomalies ( $\mathrm{Y} / \mathrm{Ho}$ 33-40) that characterize coastal or lagoonal environments (Bau et al. 1997, De Baar et al. 1985, Nozaki et al. 1997, Tostevin et al.2016). Continental water bodies have $\mathrm{Y} / \mathrm{Ho}$ ratios close to crustal and PAAS values - around 28 (McLennan, 1989). Y solubility increases in oxidizing environments (Bolhar et al. 2004), and Ho is preferably absorbed by suspended particles. Therefore, chemical sedimentation in equilibrium with seawater generates rocks with high Y/Ho ratios (Bau and Dulski 1996, Bolhar et al. 2004, Bau and Alexander 2006).

$\mathrm{Y} / \mathrm{Ho}$ ratios vary from 24 to 37 in calcsilicate rocks and from 28 to 40 in marbles of Group 1, being confined to 26-27 in marbles of Group 2. Y/Ho ratios in Group 2 marbles and calcsilicate rocks are comparable to those of non-marine carbonates (25-35) (Bolhar and Van Kranendonk 2007), with lower values for modern seawater and marine chemical sediments (Y/Ho>45) (Nozaki et al. 1997, Kamber and Webb 2001, Lawrence et al. 2006), suggesting the influx of continental freshwater and debris into the paleobasin. Samples with $\mathrm{Y} /$ Ho ratios below the PAAS value of 28 were likely formed under the influence of continental waters.

The Y/Ho versus Ce/Ce* plot presented in Figure 12A suggests that different sediment sources contributed to the genesis of lithofacies, with greater detrital contributions, such as Group 2 marbles and some calcsilicate rocks. Group 1 marbles contain less detrital material, which is consistent with low $\Sigma \mathrm{REE}, \mathrm{Al}_{2} \mathrm{O}_{3}$, and $\mathrm{Zr}$ concentrations and higher $\mathrm{MgO}+\mathrm{CaO}$ and $\mathrm{Y} / \mathrm{Ho}$ (Figs. 12B-12E). Figure 12C illustrates the compositional difference between the two marble groups. Calcsilicate rocks with a Y/Ho ratio higher than PAAS exhibit different degrees of detrital contamination, similar to those with a ratio $<28$, suggesting freshwater input to the paleobasin. Thus, the compositional differences between lithofacies should be related to differences in the rate of detrital contributions.

\section{Diagenesis}

Shields and Stille (2001) and Ling et al. (2013) demonstrated that diagenetic alteration after deposition of carbonate sediments can modify REE patterns. Nevertheless, Bau and Alexander (2006) identified primary REEY patterns in Precambrian dolomitized carbonates. Negative correlations between $\mathrm{Ce} / \mathrm{Ce}^{*}$ and $\mathrm{Dy} /$ 

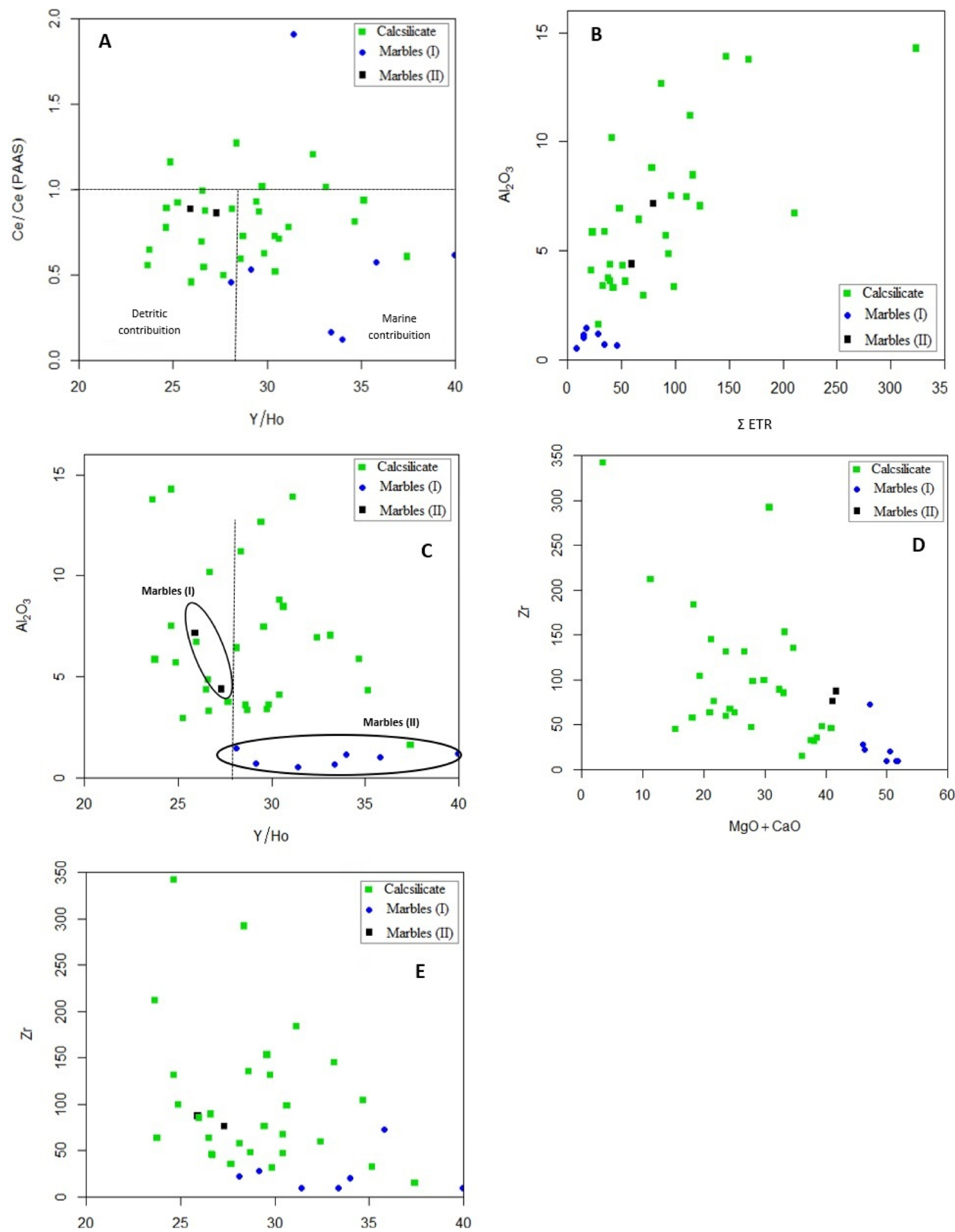

Figure 12. Ce/Ce* vs. Y/Ho diagram indicating a distinct sedimentary source for both marble groups. Largest contribution of continental water (up to $30 \mathrm{ppm}$ ) and marine water (>30), according to Kamber and Webb (2001), Ling et al. (2013). (B) $\mathrm{Al}_{2} \mathrm{O}_{3}$ vs. $\Sigma \mathrm{REE}$ (Ling et al.2013). (C) $\mathrm{Al}_{2} \mathrm{O}_{3}$ vs. $\mathrm{Y} / \mathrm{Ho}$ demonstrating the compositional difference of the two marble groups (Ling et al. 2013). (D) $\mathrm{Zr}$ vs. $\mathrm{MgO}+\mathrm{CaO}$ showing a higher detrital contribution in calcsilicates. (E) Zr vs. Y/Ho (Bolhar et al. 2004). REE: rare earth elements.

$\mathrm{Sm}_{\mathrm{N}}$ occur when REEY undergoes late diagenetic alteration (e.g., Shields and Stille 2001, Ling et al. 2013, Zhu and Jiang 2017).

Some samples of calcsilicate rocks showed a negative correlation, indicating that late diagenetic effects might have affected these samples. Group 1 marbles display a positive correlation (Fig. 13A).
In a reducing environment, $\mathrm{Eu}^{+3}$ is reduced to $\mathrm{Eu}^{+2}$ and can be easily mobilized (Bolhar and Van Kranendonk 2007). $\mathrm{Eu}$ is also thermochemically reduced in environments with temperatures above $200-250^{\circ} \mathrm{C}$ (Sverjensky 1984, Bau and Möller 1992). $\mathrm{Eu}^{+3}$ reduction might occur during extreme marine diagenesis, involving an environment rich in organic 

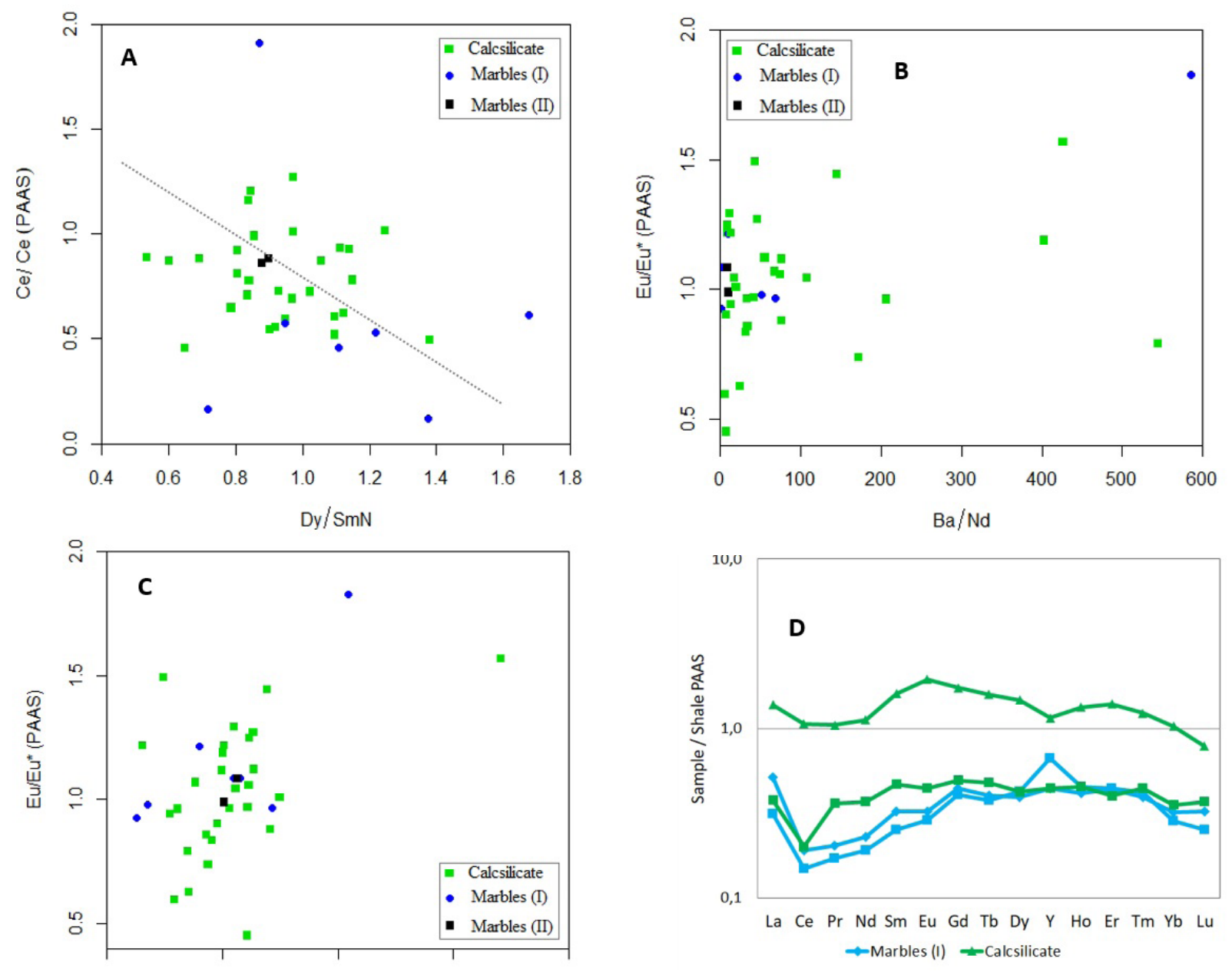

Figure 13. (A) Dy/Sm $\mathrm{N}_{\mathrm{N}}$ versus $\mathrm{Ce} / \mathrm{Ce}^{*}$. (B) $\mathrm{Eu} / \mathrm{Eu}^{*}$ versus $\mathrm{Ba} / \mathrm{Nd}$ for all samples. (C) $\mathrm{Eu} / \mathrm{Eu}^{*}$ versus $\mathrm{Pr} / \mathrm{Sm}_{\mathrm{N}^{*}}$ (D) MREE-enriched patterns in Group 1 marbles and calcsilicate. REE: rare earth elements; MREE: middle REE.

matter and sulfate (MacRae et al. 1992, Shields and Stille 2001). However, in seawater, $\mathrm{Eu}^{+3}$ is the most common valence form and is not significantly fractionated during dissolution and precipitation (Shields and Stille 2001). Negative anomalies can also be inherited from source areas or associated with percolation of reducing diagenetic and hydrothermal fluids (Bolhar et al. 2004, Zhao et al. 2018).

Positive anomalies need to be carefully investigated due to the potential isobaric overlap of $\mathrm{BaO}^{+}$and $\mathrm{BaOH}^{+}$ions on Eu during ICP-MS measurements. Thus, significant interference can sometimes cause false Eu anomalies in rocks with high Ba/Eu ratios, such as carbonates (Dulski 1994, Shields and Stille 2001, Ling et al. 2013, Zhu and Jiang 2017). In Figure $13 \mathrm{~B}, \mathrm{Ba} / \mathrm{Nd}$ ratios are $>145$ and show a positive correlation with $\mathrm{Eu} / \mathrm{Eu}^{*}$, suggesting that $\mathrm{Ba}$ interference causes artificial Eu anomalies; at the same time, samples with $\mathrm{Ba} / \mathrm{Nd}<150$ also show high $\mathrm{Eu} / \mathrm{Eu}^{*}$. Samples with $\mathrm{Ba} /$ $\mathrm{Nd}>145$ were excluded so as to investigate the relationship between $\mathrm{Eu} / \mathrm{Eu}^{*}$ and $\mathrm{Pr} / \mathrm{Sm}_{\mathrm{N}}$ in Figure $13 \mathrm{C}$. The positive correlation between $\mathrm{Eu} / \mathrm{Eu}^{*}$ and $\mathrm{Pr} / \mathrm{Sm}_{\mathrm{N}}$ indicates that $\mathrm{Eu}$ was not decoupled from the redox-insensitive REEY during diagenesis, ruling out the influence of reducing diagenetic fluids (Bolhar and Van Kranendonk 2007, Wang et al. 2018, Khelen et al. 2019).
Carbonates affected by diagenetic processes have convex-up REE patterns with enrichment of middle REE (MREE) (Bau 1993, Bau et al. 1999). Figure 13D shows REEY enrichment in some marbles and calcsilicates; nonetheless, only four samples present the characteristic convex-up REEY pattern. Thus, late diagenetic processes that caused MREE enrichment did not have a significant influence on the composition of lithofacies.

\section{Post-depositional interaction with hydrothermal fluids}

\section{Hydrothermal fluids in the paleobasin}

REEY patterns in carbonate rocks can also be affected by hydrothermalism as long as the fluid flow is high (Zhong and Mucci 1995, Zhao and Zheng 2013). Therefore, we investigated the influence of high-temperature fluids associated with fumaroles related to the opening of the paleobasin during carbonate deposition.

Positive Eu anomalies generated during deposition of marine sediments have been attributed to high-temperature hydrothermal input processes during carbonate deposition, which are also accompanied by LREE enrichment (Michard et al. 1983, Bau 1991, Alexander et al. 2008, Frimmel 2009, 
Zhu et al.2014, Joosu et al. 2015, Zhu and Jiang 2017) or by the presence of Eu in detrital sediments, mainly in calcic plagioclase.

Alexander et al. (2008) proposed a mixing model involving high-temperature hydrothermal fluids in seawater during sediment deposition, using MREE/HREE ratios. The studied samples were plotted distant from the mixing line (between 0.1 and $1 \%$ hydrothermal fluids). This scenario suggests no influence of high-temperature fluids and that the depositional environment of carbonate rocks was distant from fumaroles. Marbles were plotted in the same region as the post-Archean marine carbonates of Luzijang (Wang et al. 2018) (Figs. 14A-14C).

In addition to Eu enrichment, Barrett et al. (1988) and Khelen et al. (2019) state that the influence of hydrothermal fluids as fumarolic sources associated with the generation of mid-ocean ridge basalt (MORB) volcanic rocks can be evidenced by La anomalies. Studies of Archean stromatolites have shown that La enrichment in chemical sediments results from the increased contribution of hydrothermal solutions to seawater (Barrett et al. 1988, Khelen et al. 2019, Courtois and Treuil 1977). This enrichment was also found in studies investigating the interaction between chemical sediments and hydrothermal fluids in the Red Sea, where all chemical precipitates are enriched in La (Courtois and Treuil 1977). The positive correlation of REEY with La (Fig. 14C) indicates the preservation of the primary geochemical feature in the studied samples (except the MM-TR-56 A sample), despite the mixing with detrital sediments and possible (minor) disturbances caused by early to late diagenetic effects (Bolhar and Van Kranendonk 2007, Khelen et al. 2019).

\section{Late hydrothermalism: effects of the orogenic event}

The influence of late hydrothermal fluids is conceivably related to Paleoproterozoic orogeny and syn- and post-tectonic granites. The modern seawater pattern, when normalized to PAAS, is characterized by LREE depletion, a negative Ce anomaly, and positive La and Gd anomalies (e.g., De Baar et al. 1991, Bau and Dulski 1996, Northdurft et al. 2004, Bolhar et al. 2004, Piper and Bau 2013). In addition, seawater Y/Ho ratios are extremely high, with superchondritic values (e.g., Bau and Alexander 2006). Only three samples (two calcsilicates and one marble) show significant LREE enrichment in relation to HREE (Fig. 15A). These samples are hydrothermally
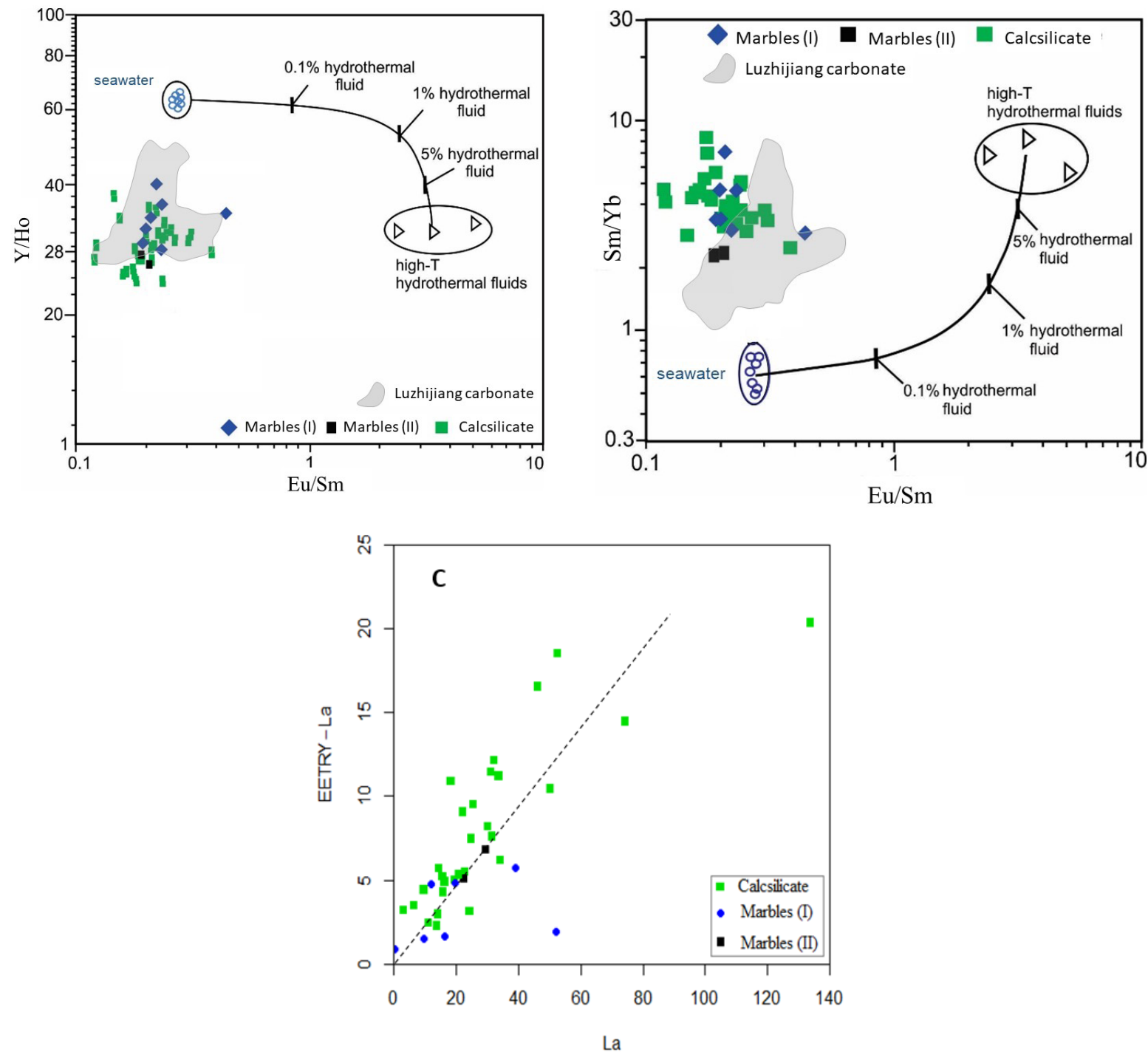

Figure 14. Eu/Sm versus (A) $\mathrm{Y} / \mathrm{Ho}$ and (B) $\mathrm{Sm} / \mathrm{Yb}$ indicating that the studied samples are plotted in shallow water and without influence of hydrothermal fluids (Alexander et al. 2008), as well marine Luzhijiang carbonate (Wang et al. 2018). (C) La vs. $\Sigma$ REEY-La (Wang et al. 2018, Khelen et al. 2019). REEY: rare earth elements and yttrium. 
altered to varying degrees, as evidenced by the presence of serpentinization, talcification, saussuritization, chloritization, and sericitization. Even considering that many samples show LREE enrichment (Fig. 15B), this enrichment did not significantly affect the REEY patterns, suggesting a hydrothermal alteration progressing under low fluid/rock ratios.

The modification of REE content in rocks by hydrothermal fluids is generally limited, and the analysis of these patterns is not always relevant for petrogenetic studies (Bau 1991). However, in a fluid-dominated system with a fluid/rock ratio $>100$, it is possible to change the REE patterns, and such changes are often marked by a relative LREE enrichment. In general, rocks that have undergone extremely fluid-dominated changes do not provide reliable data for the interpretation of their primary REE pattern or isotopic studies. In all other situations, REE content is not significantly modified by hydrothermal or metamorphic fluids during rock-fluid interaction (Bau 1991).

Thus, in most marble lithofacies studied, the REEY composition was not affected by diagenetic and fumarolic fluids in the paleobasin. Late hydrothermalism might have affected three samples, and thus these samples were excluded from the analysis of paleoenvironmental conditions. Positive and negative EU anomalies in these lithofacies are probably inherited from their sources. The Eu present in calcic plagioclase is supplied to seawater during continental weathering and transported through river waters, as is the case of the Luoxue carbonates described by Wang et al. (2018) (see also Michard et al. 1983, Kamber et al. 2004, Zhao et al. 2009). REEY patterns still preserve important characteristics of paleoenvironmental deposition conditions.

\section{Deposition conditions}

Based on considerations associated with detrital contamination, diagenesis, and hydrothermalism, we suggest using the REEY composition of marbles and calcsilicate rocks to characterize deposition conditions. Most samples studied show flat REEY-normalized patterns, with commonly negative Ce anomalies, positive $\mathrm{Y}$ and $\mathrm{Gd}$ anomalies, and highly variable $\mathrm{Eu}$ anomalies.

Shale-normalized REE patterns of seawater and marine sediment plot below the concentration ratio of 1 , while river water plots above the concentration ratio of 1 (Mohanty et al. 2015, Singh et al. 2015, Tang et al.2016). Figures 16A and 16B have shale-normalized REE distribution patterns; all samples shown are below the concentration level of 1 , suggesting a marine depositional environment (hydrothermally altered samples were excluded).

Group 1 marbles and some calcsilicate rocks present LREE depletion, low concentration of lithophile elements, high Y/Ho $>30$, and (slightly) positive La and Gd anomalies. Their REEY patterns are similar to those of marine Luzhijiang carbonates described by Wang et al. (2018) and of Devonian carbonates in the Canning Basin (Northdurft et al., 2004) (Fig. 16C). In contrast, Group 2 marbles lack pronounced anomalies and show flat REEY patterns due to the predominant contribution of siliciclastic sediments to the REEY budget. REEY patterns in sedimentary rocks are mostly controlled by the mineral phases present in the rock. REEY from Group 2 and some calcsilicate samples are enhanced by REEY contributions from detrital material. The REEY distribution is similar to that of Paleoproterozoic calcsilicate rocks from the Fuping Complex (Tang et al. 2016) in Figure 16D.

Precipitated chemical sediments in marine and non-marine environments can be differentiated by diagnostic REEY ratios relative to PAAS, such as $\mathrm{La}, \mathrm{Eu}, \mathrm{Ce}$, and $\mathrm{Gd}$ (Bolhar et al. 2004, Bolhar and Van Kranendonk 2007, Zhao et al. 2009, Johannesson et al. 2014). The behavior of these elements has been recorded for various types of chemical precipitates, such as carbonates, cherts, BIF, and phosphorites (e.g., Joosu et al. 2016), and seems remarkably consistent over geological time (Bolhar et al. 2004).

Cerium occurs as $\mathrm{Ce}^{+4}$ or $\mathrm{Ce}^{+3}$, depending on seawater oxygenation conditions (Bolhar et al. 2004, Ling et al. 2013, Tostevin et al. 2016). Increasing La concentrations in the
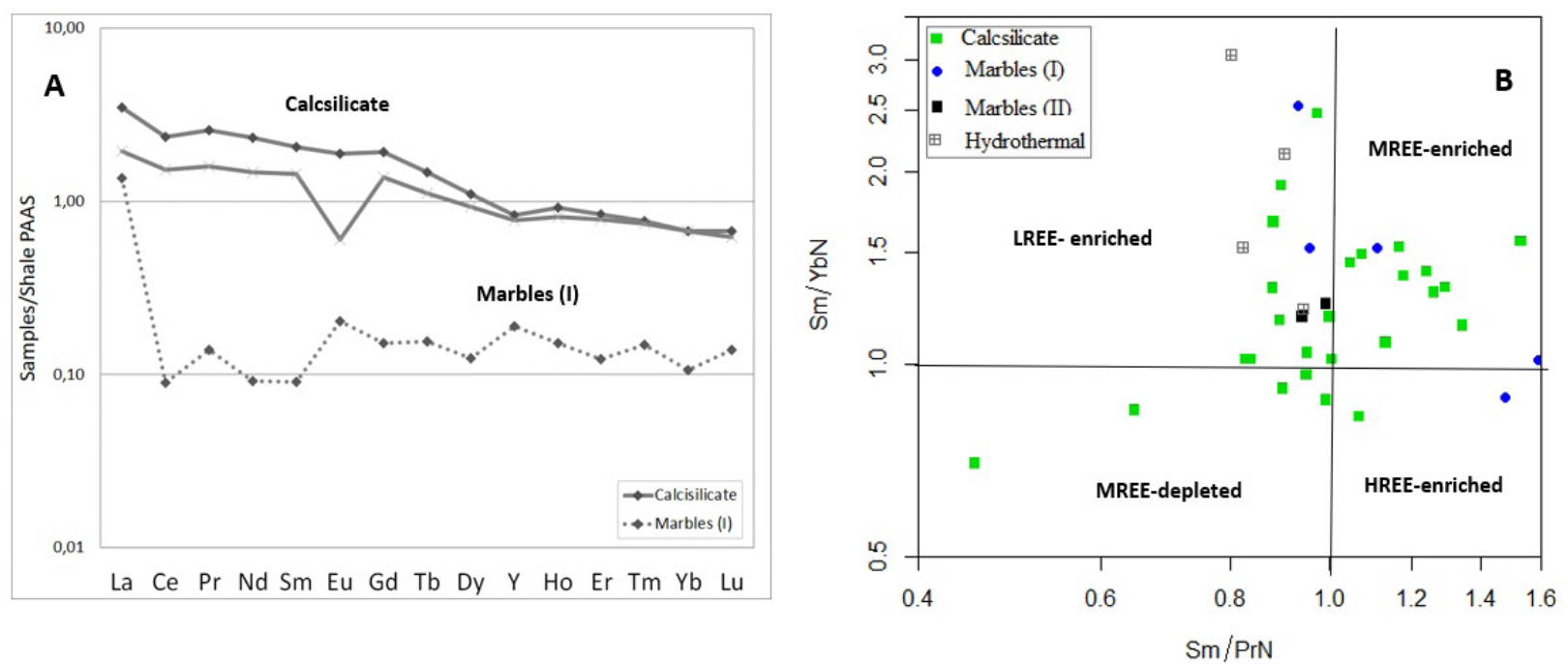

Figure 15. Distribution of REEY patterns in samples with LREE-enriched calcsilicate rocks and enriched La in marbles. (B) Binary plot of $\mathrm{Sm} / \mathrm{Yb}_{\mathrm{N}}$ and $\mathrm{Sm} / \mathrm{Pr}_{\mathrm{N}}$ evidencing LREE- and HREE-enriched samples. After Samala et al. (2018). REE: rare earth elements; REEY: REE and yttrium; LREE: light REE; HREE: heavy REE. 
Braz. J. Geol. (2021), 51(3): e20190137
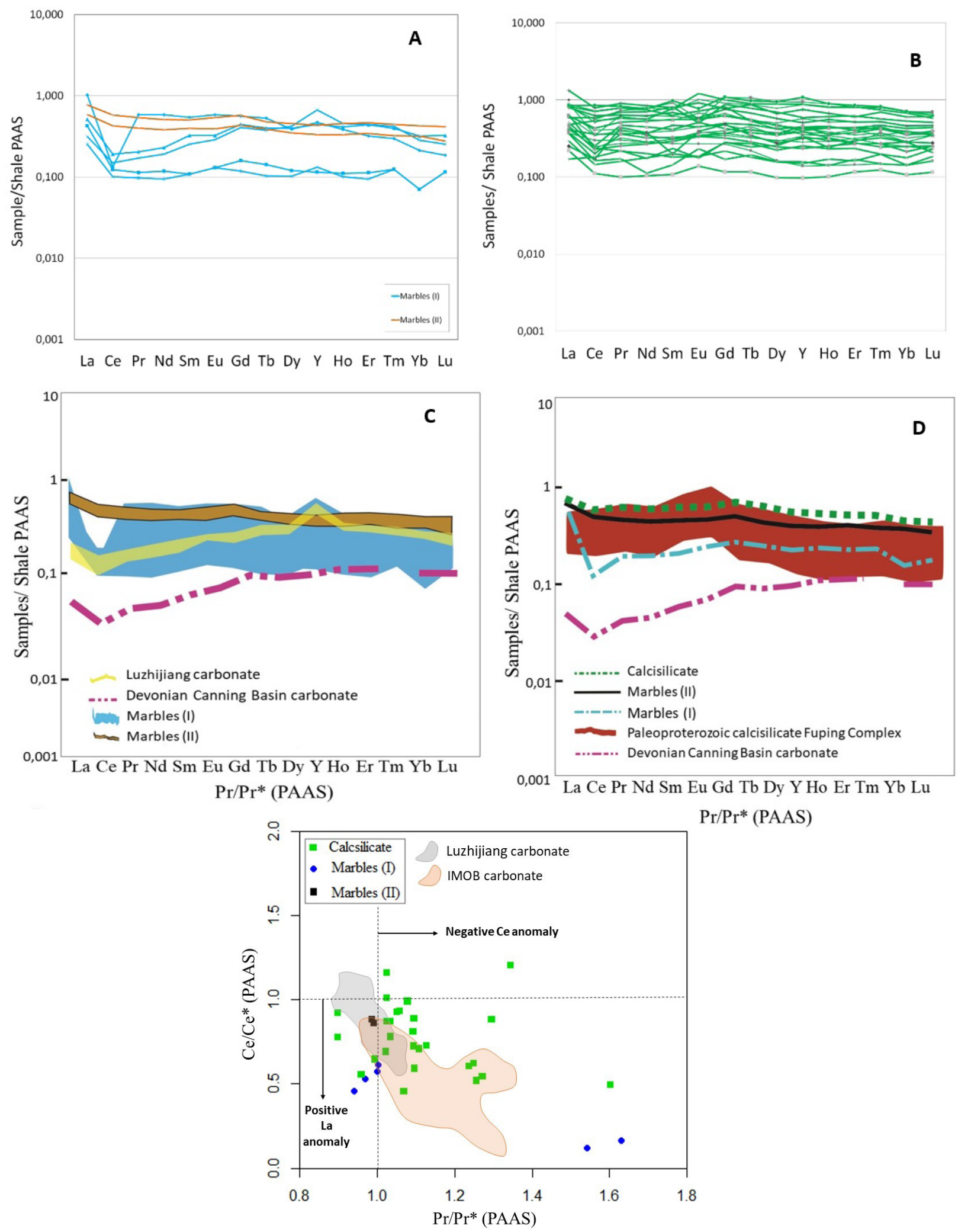

Figure 16. Distribution of REEY patterns from (A) marbles and (B) calcsilicate rocks. (C) Comparison between the REEY distribution in marbles with marine carbonates from Luzhijiang and Devonian Canning Basin (Northdurft et al. 2004). Group 1 marbles and Luzhijiang show negative Ce and positive Y. (D) Comparison between the REEY distribution of average calcsilicates and Paleoproterozoic calcsilicate rocks from the Fuping Complex (Tang et al. 2016). (E) PAAS-normalized (Ce/Ce* vs. $\left.\mathrm{Pr} / \mathrm{Pr}^{*}\right)$ diagram indicating fields of true negative and positive $\mathrm{Ce}$ anomalies, suggesting that they were deposited in an oxygenated environment (Bau and Dulski 1996 modified by Webb and Kamber 2000); comparison of marine Luzhijiang carbonate (Wang et al. 2018) and Indo-Myanmar Orogenic Belt - IMOB (Singh et al. 2015). REEY: rare earth elements and yttrium; PAAS: Post-Archean Australian Shale.

marine environment, either by diagenetic or hydrothermal processes, may mask possible Ce anomalies in seawater and its chemical precipitates. True Ce anomalies were investigated using Bau and Dulski’s (1996) technique, modified by Webb and Kamber (2000) (Fig. 16E). Most of the studied marble and calcsilicate samples showed negative Ce and positive La anomalies, similar to marine Luzhijiang carbonates (Wang et al. 2018) and the Indo-Myanmar Orogenic Belt (Singh et al. 2015). The negative $\mathrm{Ce}$ anomalies in these carbonates suggest that they were deposited in a suboxic environment. 
Modern oceans are fully oxygenated and exhibit a strong negative $\mathrm{Ce}$ anomaly $\left(\mathrm{Ce} / \mathrm{Ce}^{*}<0.55\right)$ when normalized to PAAS, except for the Black Sea (Planavsky et al. 2010, Ling et al. 2013). In the Archean, the atmosphere was anoxic, and chemical sedimentary rocks did not present $\mathrm{Ce} / \mathrm{Ce}^{*}$ anomalies $\left(\mathrm{Ce} / \mathrm{Ce}^{*} \approx 1\right)$. With increasing oxygen content in the atmosphere at the beginning of the Paleoproterozoic, the sea surface became oxygenated in relation to the Archean, with $\mathrm{Ce} / \mathrm{Ce}^{*}$ values between 1 and 0.55 (Kamber and Webb 2001, Van Kranendonk et al. 2003). Still, (early) Paleoproterozoic oceans were oxygen-deficient compared to modern oceans, generating stratified water columns with suboxic and anoxic zones (Nelson et al. 2010, Planavsky et al. 2010, Pufahl 2010, Pufahl and Hiatt 2012). The Paleoproterozoic development of the suboxic ocean surface reflects the photosynthetic oxygen production from the combination of peritidal stromatolites and cyanobacteria (Pufahl and Fralick 2004). Negative $\mathrm{Ce}$ anomalies in these metasediments indicate deposition in a suboxic environment.

Gadolinium (III) forms more stable ionic and biogenic complexes than its neighboring REE at typical marine physicochemical conditions (temperature, $\mathrm{pH}$, and pressure), leading to characteristic positive $\mathrm{Gd}$ anomalies in marine signatures (Bau 1999). Our results are consistent with these earlier findings, as Group 1 marbles have $\mathrm{Gd} / \mathrm{Gd}^{*}$ ranging from 1.04 to 1.36 , whereas Group 2 marbles show Gd/Gd* values between 1.10 and 1.15 , and calcsilicate rocks generally present
$\mathrm{Gd} / \mathrm{Gd}^{*}$ values slightly above unity, (0.94-1.16), suggesting a marine environment.

Planavsky et al. (2010) proposed that REEY patterns have a temporal trend reflecting the evolution of the redox state in the marine environment. Thus, Archean and early Paleoproterozoic (2.4 to $1.9 \mathrm{Ma}$ ) carbonates and BIFs are characterized by LREE-depleted patterns, negative $\mathrm{Ce}$ anomalies, positive $Y$ anomalies, and slightly positive $\mathrm{Gd}$ anomalies. However, these positive anomalies are not directly caused by the redox state of water but by the entry of hydrothermal fluids that are enriched in these elements (Bau 1991, Planavsky et al. 2010). These patterns are compatible with the REEY behavior of Group 1 marble and calcsilicate rock samples, with a maximum deposition age of $2128 \mathrm{Ma}$.

REEY patterns observed in continental waters with carbonate sediments, such as lake or lagoon environments, are characterized by MREE enrichments and absence of $\mathrm{La}, \mathrm{Eu}$, and $\mathrm{Y}$ anomalies (Lawrence et al. 2006, Bolhar and Van Kranendonk 2007). Therefore, given the prominent anomalies identified in our samples, we can exclude a non-marine depositional environment for the studied Paleoproterozoic lithofacies.

\section{Phosphate in metasediments and Precambrian precipitation control}

Figure 17 shows the lithostratigraphic variation found in two profiles near Bonfim-Ipirá and Sul-Ipirá. In the Tanque Novo-Ipirá Complex, the basal sequence is interpreted as an
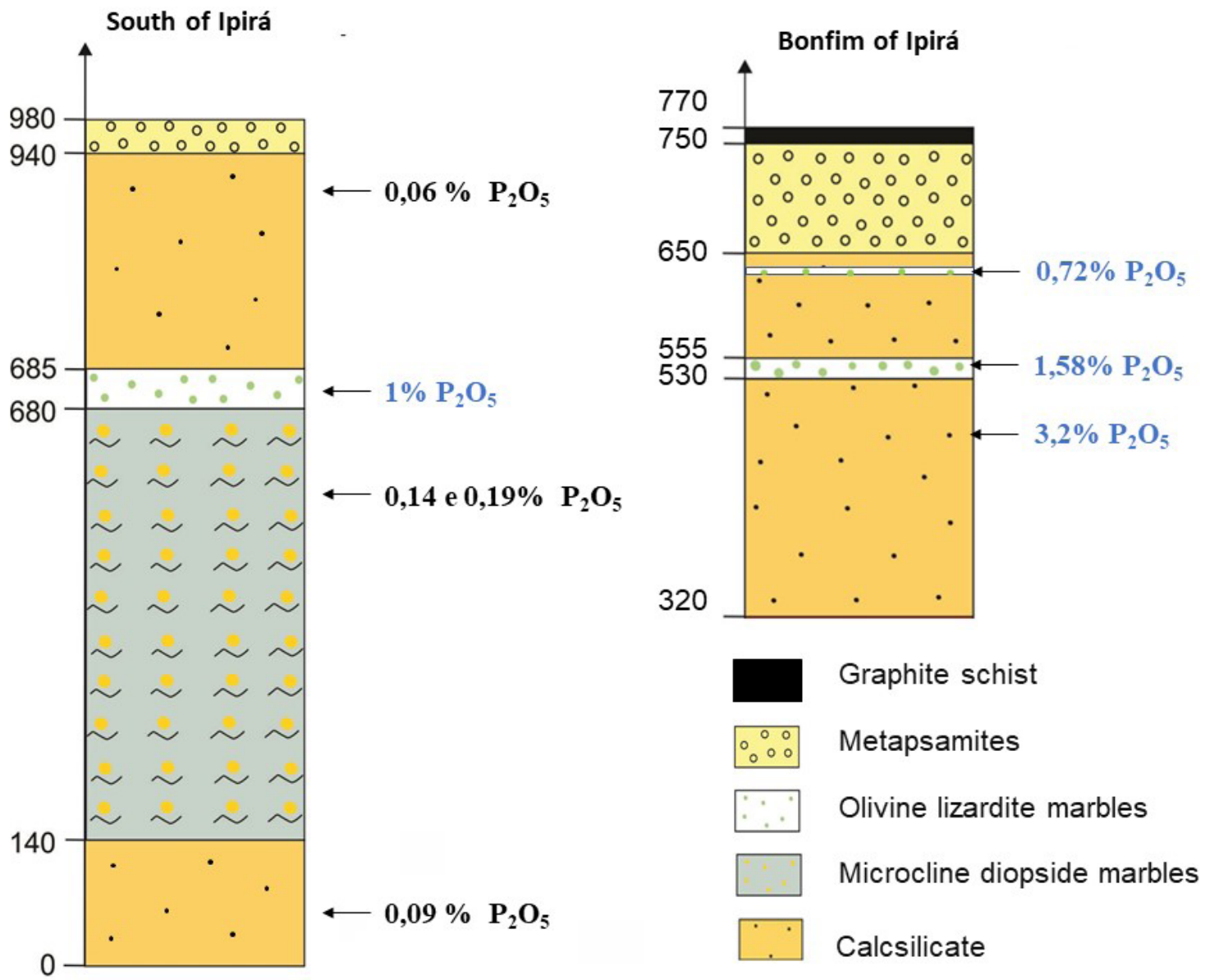

Figure 17. Correlation between lithostratigraphic columns of the region near Bonfim-Ipirá and Sul-Ipirá, evidencing the main lithofacies of the Serra do Camisão Unit. 
ocean floor sequence associated with paragneisses, kinzigites, and metabasites of the Pintadas Unit. Paragneissses are absent in the Serra do Camisão Unit — the main study area (Melo et al. 1991). The base of this unit contains marbles, diopside-rich granofels, and BIFs, followed by a siliciclastic sequence that comprises impure quartzites, metapsammites, and carbonates with graphite schist at the top.

This lithostratigraphic sequence contains phosphate and is similar to those of phosphorites in the Salitre Complex, in Juazeiro, described by Oliveira (2016). These lithofacies experienced greenschist facies metamorphism and preserve primary structures in the following sequence, from bottom to top: garnet and sericite-schist, serpentine marbles, diopside-tremolite-marbles, calcsilicate, and quartzites in the Batateira mountain range. The Ilha do Fogo profile still preserves the graphitic schist at the top of the sequence in Juazeiro, described by Oliveira (2016).

Marbles and calcsilicate rocks with positive $\mathrm{P}_{2} \mathrm{O}_{5}$ anomalies (above $0.5 \%$, up to $3.2 \%$ ) show greater marine influences, with a more carbonate than siliciclastic contribution, notably in marbles of Group 1 and some calcsilicate rocks with Y/Ho ratios $>30$ (Figs. 18A and 18B). P-mineralized samples present $\mathrm{Ce} / \mathrm{Ce}^{*}$ values between 0.53 and 1 , with an average of 0.70 , consistent with a stratified Paleoproterozoic ocean, with phosphorus in the extension of the suboxic zone (Fig. 18C).

XRD analyses in Group 1 marbles and calcsilicate rocks indicated the presence of fluorapatite with a $\mathrm{Ca}_{4.791} \mathrm{~F}_{0.93} \mathrm{Mn}_{0.211} \mathrm{P}_{3} \mathrm{O}_{12}$ composition. Previous work has shown that although francolite has a crypto-microcrystalline texture, it produces X-ray diffraction patterns similar to fluorapatite (McClellan and Lehr 1969, McClellan 1980).

Francolite progressively develops fluorapatite characteristics during weathering and diagenesis (Lucas et al. 1980, Jarvis et al. 1994, Drummond et al. 2015). One of the first modifications is decarbonation with the loss of $\mathrm{CO}_{3}^{-2}$, accompanied by leaching of other elements (McArthur, 1980, 1985). These processes are even more intense during metamorphism and can transform francolite into fluorapatite by reducing the $\mathrm{Na} / \mathrm{P}_{2} \mathrm{O}_{5}$ and $\mathrm{CO}_{2} / \mathrm{P}_{2} \mathrm{O}_{5}$ ratios in the francolite structure (McArthur 1985, Girard et al. 1993, Drummond et al. 2015). Considering these data, the studied apatites could have of synsedimentary origin. However, post-depositional decarbonation may have occurred, mainly at metamorphic conditions.

The main source of phosphorus is the weathering of continental rocks that are subsequently transported to the ocean as dissolved and particulate matter (Benitez-Nelson 2000, Filippelli 2008, 2011). Dissolved P in the marine environment mainly occurs as phosphate species, particularly $\mathrm{HPO}_{4}^{-2}$, along with $\mathrm{H}_{2} \mathrm{PO}_{4}^{-}$and $\mathrm{PO}_{4}^{-3}$ (e.g., Filippelli 2008, 2011). Bioavailable $\mathrm{P}$ particles include organic matter-rich detrital sediment, as well as clay minerals and $\mathrm{Fe}$-(oxy)hydroxides with adsorbed $\mathrm{P}$; these components are of fundamental importance for phosphorite formation (Filippelli 2008).

Phosphorus precipitation $\left(\mathrm{HPO}_{4}^{-2}\right)$ in a low-oxygen Paleoproterozoic basin could occur at the boundary between anoxic and suboxic zones in the internal carbonate platform.
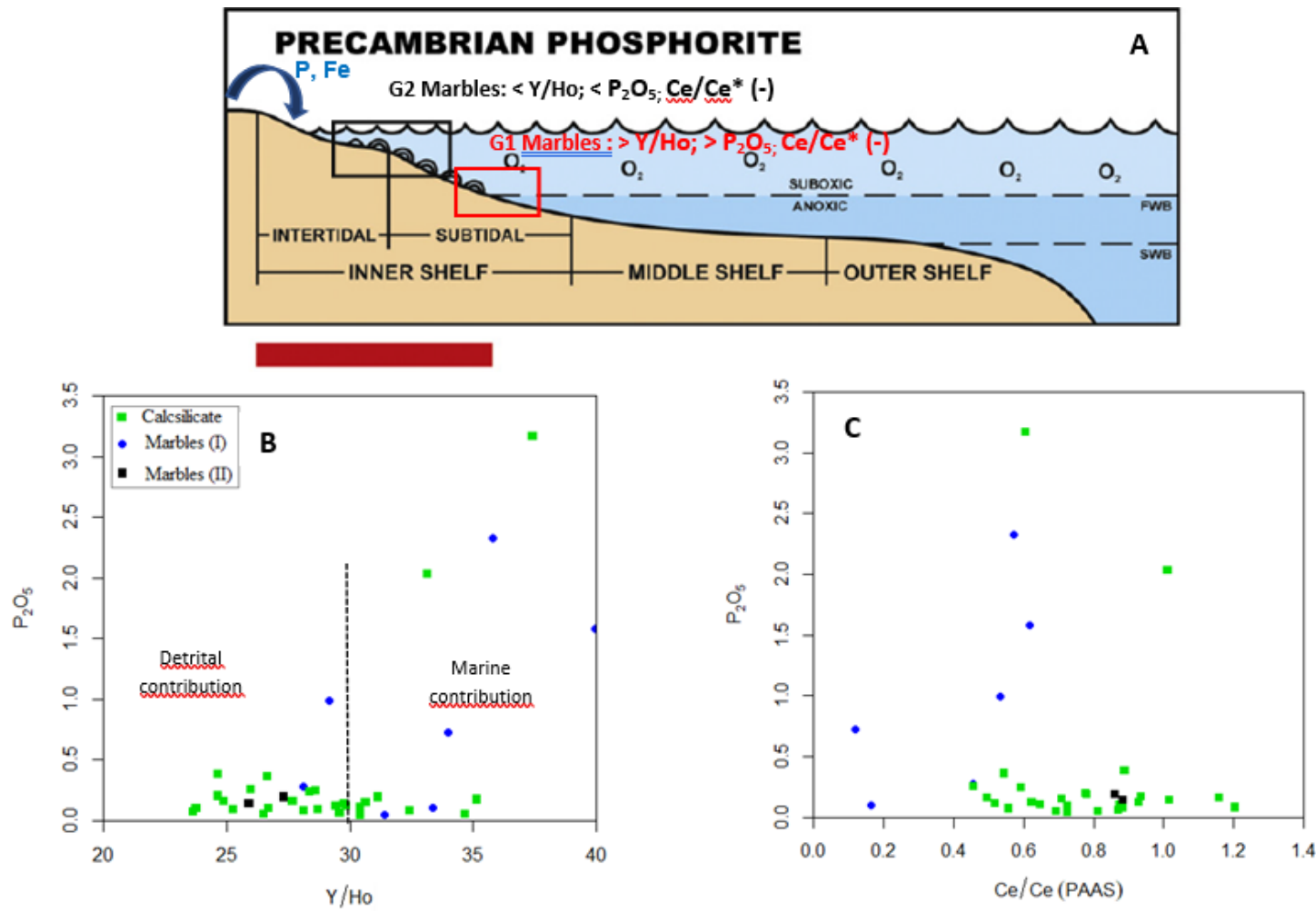

FWB: fair-weather wave base; SWB: storm wave base.

Figure 18. (A) Precambrian basin configuration and extent of phosphogenesis resulting from Fe-redox pumping. (modified from Nelson et al. 2010). The red line represents the position where Precambrian phosphates could be precipitated due to the low oxygen availability in the paleobasin. (B) Y/Ho vs. $\mathrm{P}_{2} \mathrm{O}_{5}$ plot evidencing the highest phosphorus contents in distal lithofacies near the anoxic-suboxic limit. (C) Ce/Ce* vs. $\mathrm{P}_{2} \mathrm{O}_{5}$ plot evidencing the highest phosphorus contents for $\mathrm{Ce} / \mathrm{Ce}^{*}$ values between 0.53 to 1 . 
This boundary can be found within the water column or the sediment in the case of transition from anoxic and suboxic conditions in both (Lumiste et al. 2019).

In an anoxic region, these elements become soluble due to the P-reduction by anaerobic bacteria. $\mathrm{HPO}_{4}^{-2}$ combines with $\mathrm{Ca}, \mathrm{F}$, and $\mathrm{CO}_{2}$ in seawater and subsequently precipitates as carbonate-fluorapatite or francolite in this transition zone, at the point where oxygen enters the basin (Filippelli 2008, 2011, Pufahl 2010, Nelson et al. 2010, Papineau 2010, Pufahl and Hiatt 2012, Pufahl and Groat 2017). Nelson et al. (2010) pointed out that this model does not emphasize the role of eustatic sea-level cycles, but rather the interaction between autogenic sedimentary processes and seawater oxygenation.

Deposits of Paleoproterozoic phosphate were typically formed on passive continental margins associated with coastal river mouths, creating small stratiform bodies that were accumulated parallel to the shoreline, thus producing peritidal phosphate (e.g., Nelson et al. 2010, Pufahl 2010, Drummond et al. 2015, Hiatt et al.2015, Caird et al. 2017, Pufahl and Groat 2017). Thus, precipitation of primary apatite deposits could be associated with carbonate sediments and silicate-carbonate mixing sites.

The profound changes in the Earth's atmosphere in the late Archean and early Paleoproterozoic promoted a huge increase in the amount of dissolved $\mathrm{CO}_{2}$ in oceans and, consequently, the deposition of thick carbonate sequences, mainly of dolomitic composition (Windley 1984, Hoffman and Schrag 2002). These carbonates were formed in shallow sea conditions, interdigitated with coastal beaches installed on continental shores (Windley 1984). This model is consistent with the protolith of metasediments studied in this work. The progressive mineral paragenesis observed is the result of metamorphic recrystallization of impure carbonate sediments. When subjected to regional metamorphism, there is a sequence of characteristic mineral reactions defining isogrades, involving forsterite, diopside, tremolite, calcite, dolomite, and quartz (Yardley 1989). Different degrees of alumina added to carbonates via mixing with detrital materials during depositions allow the formation of biotite, hornblende, and garnet (Winkler 1979, Berman 1991).

The P-enrichment in the studied lithofacies chronocorrelates to the first important phosphogenic episode in the geological record. Paleoproterozoic phosphogenesis began after the GOE (Nelson et al. 2010, Pufahl 2010, Pufahl and Hiatt 2012, Papineau et al. 2013). Pufahl and Hiatt (2012) demonstrated that Paleoproterozoic phosphate deposits are also accompanied by iron and organic carbon deposits.

Paleoproterozoic oxygenation extended through time and was related to deglaciation periods, such as the Huronian deglaciation (Pufahl and Hiatt 2012), which is compatible with the maximum age of deposition of these metasedimentary successions. The continental exposure due to sea-level elevation during deglaciation facilitated the chemical weathering of these rocks and increased the terrestrial input to the marine environment (e.g., Nelson et al. 2010, Papineau 2010, Pufahl 2010, Pufahl and Hiatt 2012, Pufahl and Groat 2017).

The geochronological data obtained in this study indicate a maximum age of $2128 \mathrm{Ma}$ (youngest zircon) for the deposition of metasedimentary rocks. However, the U-Pb zircon core concordant age of $2595 \pm 18$ Ma obtained for this Complex suggests that this succession has Paleoproterozoic and Neoarchean sources. The sediments deposited in the paleobasin might have originated from the erosion of the Archean terrane (or at least a terrane with an Archean inheritance), as the oldest inherited zircon cores are in the 2573-2736 Ma range. Another population has zircon core inherited from Paleoproterozoic, between 2453 and $2128 \mathrm{Ma}$, and phosphogenesis coincided with the Huronian deglaciation, which began around $2.4 \mathrm{Ga}$ (Papineau 2010, Pufahl and Hiatt 2012, Soares 2019).

The Salvador-Curaçá Orogen contains several rocks that may be compatible with Neoarchean zircons: the Caraíba Complex, for which the U-Pb SHRIMP data obtained for tonalitic and enderbitic granulites define two populations of different ages (2.7-2.6 Ga and 2.08-2.07 Ga, respectively), preserved in zircon cores and edges (Silva et al. 1997); gabronorite from the São José do Jacuípe Suite, yielding an age of $2.69 \mathrm{Ga}$, as indicated by the U-Pb SHRIMP method on zircons (Silva 1996).

The most prominent source rock is contemporaneous with the Caraíba norite - $2580 \mathrm{Ma}$ (U-Pb SHRIMP; Oliveira et al. 2002). Zircon rims record a metamorphic event at $2082 \pm 14 \mathrm{Ma}$, interpreted to reflect the closure of the paleobasin and the formation of the Salvador-Curaça Orogen. This last event is related to the collision of the Archean Gavião and Serrinha blocks (Barbosa and Sabaté 2003, 2004).

\section{CONCLUSIONS}

Calcsilicate rocks and marbles of the Tanque Novo-Ipirá Complex are derived from the regional metamorphism of carbonates and siliciclastic sediments.

Major and trace element patterns are strongly controlled by the presence of siliciclastic phases in the marbles, especially in those from Group 2, which present flat REEY patterns. The inferred metamorphic recrystallization (amphibolite-granulite transitional conditions), as well as retrograde hydrothermal processes, did not significantly affect the immobile geochemical signatures observed in the marbles and calcsilicate rocks. Evidence of a sedimentary protolith deposited in a marine environment is clear through their marine-type REEY patterns, with characteristic negative $\mathrm{Ce}$ anomalies and positive $\mathrm{Y}$ and Gd anomalies. Negative Ce anomalies indicate at least local oxidizing conditions in the Paleoproterozoic basin, allowing stabilization of $\mathrm{Ce}^{+4}$ and, consequently, carbonate and phosphorus precipitation through mixing at the boundary zone between anoxic and suboxic zones.

The high $\mathrm{P}_{2} \mathrm{O}_{5}$ contents verified in metasedimentary rocks of the Tanque Novo-Ipirá Complex, ranging from 0.01 to $3.2 \%$, particularly in calcsilicate rocks, suggest a potential for phosphate mineralization. The highest contents are found in Group 1 calcsilicate rocks and marbles, which present $\mathrm{Ce} / \mathrm{Ce}^{*}$ values between 0.53 to 1.0 , with a mean of 0.70 , interpreted herein as suboxic conditions, reflecting the low oxygen availability during the Paleoproterozoic.

In summary, the data presented in this paper indicate that the study area was a Paleoproterozoic continental-margin 
carbonate platform subject to variable detrital input. The negative $\mathrm{Ce}$ anomalies in mineralized lithofacies (Group 1 marbles and calcsilicates) are between 0.53 to 1.0 , with an average of 0.70 , corresponding to a suboxic environment. Phosphate precipitation is compatible with the model presented by Nelson et al. (2010), in which precipitation would have occurred at the boundary between anoxic and suboxic zones.

\section{ACKNOWLEDGMENTS}

The authors thank the Baiana Mineral Research Company for their field support and technical research funding and the UFBA Electron Microscopy (LAMUME) and Mineral Technology laboratories for their support. This study was partially funded by the Coordenação de Aperfeiçoamento de Pessoal de Nível Superior - Brazil (CAPES) - Finance Code 001.

\section{ARTICLE INFORMATION}

Manuscript ID: 20190137. Received on: 12/22/2019. Approved on: 03/31/2021.

A.M. supervised the entire manuscript, making corrections and suggestions. L.O. made compilations on the ages of metasedimentary rocks and corrections to petrography, lithogeochemistry, and the manuscript process. J.S. provided data on regional geology, assisted in fieldwork and contributed to the manuscript. D.D. assisted in the revision of geochronological and lithogeochemical data and reviewed the manuscript. I.C. prepared Figures 3, 14A, 14B, 16C, 16D, and 17 and assisted in the review of petrography.

Competing interests: The authors declare no competing interests.

\section{REFERENCES}

Alexander B.W., Bau M., Andersson P., Dulski P. 2008. Continentallyderived solutes in shallow Archean seawater: rare earth element and $\mathrm{Nd}$ isotope evidence in iron formation from the 2.9 Ga Pongola Supergroup, South Africa. Geochimica et Cosmochimica Acta, 72(2):378-394. https:// doi.org/10.1016/j.gca.2007.10.028

Alkmim F.F., Neves B.B., Alves J.A.C. 1993. Arcabouço tectônico do Cráton do São Francisco: uma revisão. O Cráton do São Francisco, 45-62.

Barbosa J.S.F., Dominguez J.M.L. 1996. Geologia da Bahia: texto explicativo [para o mapa geológico do Estado da Bahia, escala 1:1.000.000. 45 p.

Barbosa J.S.F., Sabaté P. 2003. Marinho, M. M. O Cráton do São Francisco na Bahia: uma síntese. Revista Brasileira de Geociências, 33:3-6.

Barbosa J.S.F., Sabaté P. 2004. Archean and Paleoproterozoic crust of the São Francisco cráton, Bahia, Brazil: geodynamic feactures. Precambrian Research, 133(3):1-27. https://doi.org/10.1016/j.precamres.2004.03.001

Barrett T.J., Fralick P.W., Jarvis I. 1988. Rare-earth-element geochemistry of some Archean iron formations north of Lake Superior, Ontario. Canadian Journal of Earth Science, 25(4):570-580. https://doi.org/10.1139/e88-055

Bau M. 1991. Rare-earth element mobility during hydrothermal and metamorphic fluid - rock interaction and the significance of the oxidation state of europium. Chemical Geology, 93(3-4):219-230. https://doi. org/10.1016/0009-2541(91)90115-8

Bau M. 1993. Effects of syn-depositional and postdepositional processes on the rare-earth element distribution in Precambrian iron-formations. European Journal of Mineralogy, 5(2):257-267.

Bau M. 1999. Scavenging of dissolved yttrium and rare earths by precipitating iron oxyhydroxide: experimental evidence for Ce oxidation, Y-Ho fractionation, and lanthanide tetrad effect. Geochimica et Cosmochimica Acta, 63(1):67-77. https://doi.org/10.1016/S0016-7037(99)00014-9

Bau M., Alexander B. 2006. Preservation of primary REE patterns without Ce anomaly during dolomitization of Mid-Paleoproterozoic limestone and the potential re-establishment of marine anoxia immediately after the "Great Oxidation Event". South African Journal of Geology, 109(1-2):81-86. https://doi.org/10.2113/gssajg.109.1-2.81

BauM.,DulskiP.1996.Distribution ofyttriumandrare-earthelementsinthePenge and Kuruman iron-formations, Transvaal Supergroup, South Africa. Precambrian Research, 79(1-2):37-55. https://doi.org/10.1016/0301-9268(95)00087-9

Bau M., Möller P. 1992. Rare-earth element fractionation in metamorphogenic hydrothermal calcite, magnesite and siderite. Mineralogy and Petrology, 45(3-4):231-246. https://ui.adsabs.harvard.edu/ link_gateway/1992MinPe..45..231B/doi:10.1007/BF01163114

Bau M., Möller P., Dulski P. 1997. Yttrium and lanthanides in eastern Mediterranean seawater and their fractionation during redox-cycling. Marine Chemistry, 56(1-2):123-131. https://doi.org/10.1016/ S0304-4203(96)00091-6
Bau M., Romer R., Lüders V., Beukes N.J. 1999. Pb, O, and C isotopes in silicified Mooidraai dolomite (Transvaal Supergroup, South Africa): implications for the composition of Paleoproterozoic seawater and "dating" the increase of oxygen in the Precambrian atmosphere. Earth and Planetary Science Letters, 174(1-2):43-57. https://doi.org/10.1016/ S0012-821X(99)00261-7

Benitez-Nelson C.R. 2000. The biogeochemical cycling of phosphorus in marine systems. Earth-Science Reviews, 51(1-4):109-135. https://doi org/10.1016/S0012-8252(00)00018-0

Berman R.G. 1991. Thermobarometry using multi-equilibrium calculations a new technique, with petrological applications. Canadian Mineralogist, 29(4):833-855

Bolhar R., Kamber B.S., Moorbath S., Fedo C.M., Whitehouse M.J. 2004 Characterisation of early Archaean chemical sediments by trace element signatures. Earth and Planetary Science Letters, 222(1):43-60. https://doi. org/10.1016/j.epsl.2004.02.016

Bolhar R., Van Kranendonk M.J. 2007. A non-marine depositional setting for the northern Fortescue Group, Pilbara Craton, inferred from trace element geochemistry of stromatolitic carbonates. Precambrian Research, 155(3-4):229-250. https://doi.org/10.1016/j.precamres.2007.02.002

Borisov M.V., Bychkov D.A., Phelintseva N.F., Ivleva E.A. 2018 Fractionation of Rare-Earth Elements in the Processes of Hydrothermal Ore Formation. Moscow University Geology Bulletin, 73:451-456. https:// doi.org/10.3103/S0145875218050034

Bucher K., Grapes R. 2010. Petrogenesis of metamorphic rocks. 8. ed. London: Springer, $144 \mathrm{p}$.

Caird R.A., Pufahl P.K., Hiatt E.E., Abram M.B., Rocha A.J.D., Kyser T.K. 2017. Ediacaran stromatolites and intertidal phosphorite of the Salitre Formation, Brazil: Phosphogenesis during the Neoproterozoic Oxygenation Event. Sedimentary Geology, 350:55-71. https://doi.org/10.1016/j. sedgeo.2017.01.005

Cullers R.L., Yeh L.T., Chaudhury S.C.V., Guidotti C.V. 1974. Rare earth elements in Silurian pelitic schists from NW marine. Geochimica et Cosmochimica Acta, 38(3):389-400. https://doi. org/10.1016/0016-7037(74)90133-1

Courtois C., Treuil M. 1977. Distribution des terres rares et de quelques élémentsentracedanslessédiments récentsdesfosses delaMerRouge. Chemical Geology, 20:57-72. https://doi.org/10.1016/0009-2541(77)90035-3

De Baar H.J.W., Bacon M.P., Brewer P.G., Bruland K.W. 1985. Rare earth elements in the Atlantic and Pacific Oceans. Geochimica et Cosmochimica Acta, 49(9): 1943-1959. https://doi.org/10.1016/0016-7037(85)90089-4

De Baar H.J.W., Schijf J., Byme R.H. 1991. Solution chemistry of the rare earth elements in seawater. European Journal of Solid State and Inorganic Chemistry, 28(Suppl.):357-373. 
Drummond J.B., Pufahl P.K., Porto C.G., Carvalho M. 2015. Neoproterozoic peritidal phosphorite from the Sete Lagoas Formation (Brazil) and the Precambrian phosphorus cycle. Sedimentology, 62(7):1978-2008. https:// doi.org/10.1111/sed.12214

Dulski P. 1994. Interferences of oxide, hydroxide and chlorite analyte species in the determination of rare-earth elements in geological samples by inductively - coupled plasma-mass spectrum REEY. Fresenius' Journal of Analytical Chemistry, 350:194-203. https://doi.org/10.1007/BF00322470

Evans B.W. 2010. Lizardite versus antigorite serpentinite: Magnetite, hydrogen, and life (?). Geology, 38(10):879-882. https://doi.org/10.1130/ G31158.1

Filippelli G.M. 2008. The global phosphorus cycle: Past, present, and future. Elements, 4(2):89-95. https://doi.org/10.2113/GSELEMENTS.4.2.89

Filippelli G.M. 2011. Phosphate rock formation and marine phosphorus geochemistry: The deep time perspective. Chemosphere, 84(6):759-766. https://doi.org/10.1016/j.chemosphere.2011.02.019

Frimmel H.E. 2009. Trace element distribution in Neoproterozoic carbonates as palaeoenvironmental indicator. Chemical Geology, 258(34):338-353. https://doi.org/10.1016/j.chemgeo.2008.10.033

Girard J.-P., Flicoteaux R., Walter A.-V., Savin S.M., Nahon D. 1993. Oxygen and carbon stable isotope composition of structural carbonate in weathering apatites from laterites, southern Brazil and western Senegal. Applied Geochemistry, 8(6):617-632. https://doi. org/10.1016/0883-2927(93)90017-B

Glenn C.R., Follmi K.B., Riggs S.R., Baturin G.N., Grimm K.A., Trappe J., Abed A.M., Galli-Olivier C., Garrison R.R., Ilyin A.V., Jehl C., Rohrlich V., Sadaqah R.M.Y., Schidlowski M., Sheldon R.P., Siegmund H. 1994. Phosphorus and phosphorites: sedimentology and environments of formation. Eclogae Geologicae Helveticae, 87:747-788.

Hiatt E.E, Pufahl P.K, Edwards C.T. 2015. Sedimentary phosphate and associated fossil bacteria in a Paleoproterozoic tidal flat in the $1.85 \mathrm{Ga}$ Michigamme Formation, Michigan, USA. Sedimentary Geology, 319:24-39. https://doi.org/10.1016/j.sedgeo.2015.01.006

Hoffman F., Schrag D.P. 2002. The snowball Earth hypothesis: testing the limits of global change. Terra Nova, 14(3):129-155. https://doi. org/10.1046/j.1365-3121.2002.00408.x

Jackson S.E., Pearson J.P., Griffin W.L., Belousova E.A. 2004. The Application of Laser Ablation - inductively Coupled Plasma - mass Spectrometry to in situ Inserida: U-Pb Zircon Geochronology. Chemical Geology, 211 (1-2):4769. http://dx.doi.org/10.1016/j.chemgeo.2004.06.017

Jarvis I., Burnett W.C., Nathan Y., Almbaydin F.S.M., Attia A.K.M., Castro L.N., Flicoteaux R., Hilmy M.E., Husain V., Qutawnah A.A., Serjani A., Zanin Y.N. 1994. Phosphorite geochemistry-state-of-the-art and environmental concerns. Eclogae Geologicae Helveticae, 87(3):643-700.

Johannesson K.H., Telfeyan K., Chevis D.A., Rosenheim B.E., Leybourne M.I. 2014. Rare Earth elements in stromatolites - 1. Evidence that modern terrestrial stromatolites fractionate rare Earth elements during incorporation from ambient Waters. Evolution of Archean Crust and Early Life, 385-411.

Joosu L., Lepland A., Kirsimäe K., Romashkin A.E., Roberts N.M.W., Martin A.P., $C^{\mathrm{v}}$ rne A.E. 2015. The REE-composition and petrography of apatite in $2 \mathrm{Ga}$ Zaonega Formation, Russia: The environmental setting for phosphogenesis. Chemical Geology, 395:88-107. https://doi.org/10.1016/j. chemgeo.2014.11.013

Joosu L., Lepland A., Kreitsmann T., Upraus K., Roberts N.M.W., Paiste P., Martin A.P., Kirsimäe K. 2016. Petrography and the REE-composition of apatite in the Paleoproterozoic Pilgujarvi Sedimentary Formation, Pechenga Greenstone Belt, Russia. Geochimica et Cosmochimica Acta, 186:135-153. https://doi.org/10.1016/j.gca.2016.04.043

Kamber B.S., Bolhar R., Webb G.E. 2004. Geochemistry of late Archaean stromatolites from Zimbabwe: evidence for microbial life in restricted epicontinental seas. Precambrian Research, 132(4):379-399. https://doi. org/10.1016/j.precamres.2004.03.006

Kamber B.S., Webb G.E. 2001. The geochemistry of late Archean microbial carbonate: implications for ocean chemistry and continental erosion history. Geochimica et Cosmochimica Acta, 65(15):2509-2525. https://doi. org/10.1016/S0016-7037(01)00613-5
Khelen C., Manikyamba C., Subramanyam K.S.V., Santosh M., Sohini Ganguly M.S., Kalpana M.S., Subba Rao D.V. 2019. Archean seawater composition and depositional environment-Geochemical and isotopic signatures from the stromatolitic carbonates of Dharwar Craton, India Arubam. Precambrian Research, 330:35-57. https://doi.org/10.1016/j. precamres.2019.04.020

Kosin M.D., Melo R.C., Souza J.D., Oliveira E.P., Carvalho M.J., Leite C.M.M. 2003. Geologia do segmento norte do Orógeno Itabuna-SalvadorCuraçá e guia de excursão. Revista Brasileira de Geociências, 33(1):15-26.

Lawrence M.G., Greig M., Collerson K.D., Kamber B.S. 2006. Rare Earth element and yttrium variability in South East Queensland waterways. Aquatic Geochemistry, 12:39-72. https://doi.org/10.1007/s10498-005-4471-8

Leite C.M.M. 2002. A evolução geodinâmica da orogênese paleoproterozóica nas regiões de Capim Grosso-Jacobina e Pintadas-Mundo Novo (Bahia-Brasil): metamorfismo, anatexia crustal e tectônica. PhD Thesis, Universidade Federal da Bahia, Instituto de Geociências, Salvador.

Ling H., Chen X., Li D., Wang D., Shields-Zhou G., Zhu M. 2013. Cerium anomaly variations in Ediacaran - earliest Cambrian carbonates from the Yangtze Gorges área, South China: Implications for oxygenation of coeval shallow seawater. Precambrian Research, 225:110-127. https://doi. org/10.1016/j.precamres.2011.10.011

Lucas J., Prevot L., Lambay M. 1980. Charactères pétrographiques et microchimiques de phos-pharites précambrians au Bassin des Voltas (Afrique de l'Ouest). Considerations génétiques: Bulletin de la Société Géologique de France, 5:515-524.

Ludwig K.R. 2003. Isoplot 3.0: A geochronological toolkit for Microsoft Excel. Berkeley Geochronology Center, Berkeley, 70.

Lumiste K., Mand K., Bailey J., Paiste P., Lang L., Lepland A., Kirsimae K. 2019. REE+Y uptake and diagenesis in Recent sedimentary apatites. Chemical Geology, 525:268-281. https://doi.org/10.1016/j.chemgeo.2019.07.034

MacRae N.D., Nesbitt H.W., Kronberg B.I. 1992. Development of a positive Eu anomaly during diagenesis. Earth and Planetary Science Letters, 109(34):585-591. https://doi.org/10.1016/0012-821X(92)90116-D

McArthur J.M. 1980. Post-depositional alteration of the carbonatefluorapatite phase of Moroccan phosphorites. In: Bentor Y.K., ed. Marine phosphorites: geochemistry, occurrence and genesis. SEPM Special Publication, 29:53-60.

McArthur J.M. 1985. Francolite geochemistry-compositional controls during formation, diagenesis, metamorphismandweathering. GeochimicaetCosmochimica Acta, 49(1):23-35. https://doi.org/10.1016/0016-7037(85)90188-7

McClellan G.H. 1980. Mineralogy of carbonate fluorapatites. Journal of the Geological Society, 137(6):675-681.https://doi.org/10.1144/gsigs.137.6.0675

McClellan G.H., Lehr J.R. 1969. Crystal - chemical investigation of natural apatites. American Mineralogist, 54(9-10):1374-1391.

McLennan S.M. 1989. Rare earth elements in sedimentary rocks; influence of provenance and sedimentary processes. Reviews in Mineralogy and Geochemistry, 21(1):169-200.

Melo R.C. de (ed.). 1991. Pintadas, folha SC.24-Y-D-V: Estado da Bahia: texto explicativo. Salvador: CPRM. Programa Levantamentos Geológicos Básicos do Brasil, 96 p.

Michard A., Albarède F., Michard G., Minster J.F., Charlou J.L. 1983. RareEarth elements and uranium in high - temperature solutions from the East Pacific Rise hydrothermal vent field (13 $\left.{ }^{\circ} \mathrm{N}\right)$. Nature, 303(5920):795-797. https://doi.org/10.1038/303795a0

Mohanty S.P., BarikA., Sarangi S., Sarkar A. 2015. Carbon and oxygen isotope systematics of a Paleoproterozoic cap-carbonate sequence from the Sausar Group, Central India. Palaeogeography, Palaeoclimatology and Palaeoecology, 417:195-209. http://dx.doi.org/10.1016/j.palaeo.2014.10.036

Nelson G.J., Pufahl P.K., Hiatt E.E. 2010. Paleoceanographic constraints on Precambrian phosphorite accumulation, Baraga Group, Michigan, USA. Sedimentary Geology, 226(1-4):9-21. https://doi.org/10.1016/j. sedgeo.2010.02.001

Northdurft L.D, Webb G.E, Kamber B.S. 2004. Rare earth element geochemistry of Late Devonian reefal carbonates, Canning Basin Western Australia: confirmation of a seawater REE proxy in anciente limestones. Geochimica et Cosmochimica Acta, 68(2):263-283. https://doi. org/10.1016/S0016-7037(03)00422-8 
Nozaki Y., Zhang J., Amakawa H. 1997. The fractionation between Y and Ho in the marine environment. Earth and Planetary Science Letters, 148(12):329-340. https://doi.org/10.1016/S0012-821X(97)00034-4

Oliveira A.F.T. 1976. Petrology and Geochemistry of Marble and calcisilicate, Ipirá-BA. MS Dissertation, Instituto de Geociências, Universidade Federal da Bahia, Salvador

Oliveira E.P., McNaughton N.J., Armstrong R. 2010. Mesoarchaean to paleoproterozoic growth of the northern segment of the Itabuna Salvador-Curaçá orogen, São Francisco Craton, Brazil. In: Kusky T.M., Zhai M.G., Xiao W. (eds.). The evolving continents: understanding processes of continental growth. London, Geological Society of London, Special Publications, 338, 263-286.

Oliveira E.P., Mello E.F., Mcnaughton N., Choudhur, A. 2002. SHRIMP $\mathrm{U}-\mathrm{Pb}$ age of the basement to the Rio Itapicuru Greenstone Belt, NE São Francisco craton. In: Congresso Brasileiro de Geologia, 41., João Pessoa. Anais..

Oliveira L.R. 2016. Fosforitos da região de Juazeiro, Bahia: Paleoambientes, Geocronologia, Controles da Mineralização e correlações estratigráficas. MS Dissertation, Instituto de Geociências, Universidade Federal da Bahia, Salvador, $177 \mathrm{p}$.

Papineau D. 2010. Global biogeochemical changes at both ends of Proterozoic: insights from phosphorites. Astrobiology, 10(2):165-181. https://doi.org/10.1089/ast.2009.0360

Papineau D., Purohit R., Fogel M., Shields-Zhou G.A. 2013. High phosphate availability as a possible cause for massive cyanobacterial production of oxygen in the Paleoproterozoic atmosphere. Earth and Planetary Science Letters, 362:225-236. https://doi.org/10.1016/j. epsl.2012.11.050

Piper D.Z., Bau M. 2013. Normalized Rare Earth Elements in Water, Sediments, and Wine: Identifying Sources and Environmental Redox Conditions. American Journal of Analytical Chemistry, 4(10A):69-83. http://dx.doi.org/10.4236/ajac.2013.410A1009

Planavsky N., Bekker A., Rouxel O.J., Kamber B., Hofmann A., Knudsen A., Lyons T.W. 2010. Rare earth element and yttrium compositions of Archean and Paleoproterozoic $\mathrm{Fe}$ formations revisited: new perspectives on the significance and mechanisms of deposition. Geochimica et Cosmochimica, 74(22):6387-6405. https://doi. org/10.1016/j.gca.2010.07.021

Polleto K. 2014. Caracterização petrográfica, litogeoquímica, geofísica e mineralizações de fosfato associadas às rochas supracrustais da unidade serra do camisão, Ipirá - Bahia. Monography, Instituto de Geociências, Universidade Federal da Bahia, Salvador, $102 \mathrm{p}$

Pufahl P.K. 2010. Bioelemental sediments. In: James N.P., Dalrymple R.W., eds. Facies models, Geological Association of Canada. 4. ed. St John's: Geological Association of Canada, p. 477-503.

Pufahl P.K., Fralick P.W. 2004. Depositional controls on Paleoproterozoic iron formation accumulation, Gogebic Range, Lake Superior Region, USA. Sedimentology, 51(4):791-808. https://doi. org/10.1111/j.1365-3091.2004.00651.x

Pufahl P.K., Groat L.A. 2017. Sedimentary and Igneous Phosphate Deposits: Formation and Exploration an invited paper. Economic Geology, 112 (3):483-516. https://doi.org/10.2113/econgeo.112.3.483

Pufahl P.K., Hiatt E.E. 2012. Oxygenation of the Earth's atmosphereocean system: a review of physical and chemical sedimentologic responses. Marine and Petroleum Geology, 32(1):1-20. https://doi.org/10.1016/j. marpetgeo.2011.12.002

Ribeiro T.S. 2016. Caracterização Geológica das Rochas Calcissilicáticas e Metacarbonáticas do Complexo Tanque Novo- Ipirá na Folha Pintadas-Ba: Potencial Metalogenético para Fosfato, Salvador. MS Dissertation, Instituto de Geociências, Universidade Federal de Bahia, Salvador, 181 p.

Samala W., Khirekesh Z., Amini A., Bafti B.S. 2018. Diagenetic evolution of the upper Devonian phosphorites, Alborz Mountain Range, northern Iran. Sedimentary Geology, 376:90-112. https://doi.org/10.1016/j. sedgeo.2018.08.001

Sato K., Tassinari C.C.G., Kawashita K., Petronilho L. 1995. O método Geocronológico Sm-Nd no IG/USP e suas aplicações. Anais da Academia Brasileira de Ciências, 67(3):315-336.
Shields G., Stille P. 2001. Diagenetic constraints on the use of cerium anomalies as palaeoseawater redox proxies: an isotopic and REE study of Cambrian phosphorites. Chemical Geology, 175(1-2):29-48. https://doi. org/10.1016/S0009-2541(00)00362-4

Silva L.C., Mcnaughton N.J., Melo R.C., Fletcher I.R. 1997. U-Pb SHRIMP ages in the Itabuna-Caraíba TTG hight-grade Complex: the first window beyond the Paleoproterozoic overprint of the eastern Jequié Craton, NE Brazil. In: International Symposium on Granites and Association. Mineralis, 1, 282-283. Abstracts... Salvador.

Silva M.G. 1996. Sequências metassedimentares, vulcanossedimentares e greenstone belts do Arqueano e Proterozóico inferior. In: Barbosa J.S.F., Dominguez J.M.L. (eds.). Geologia da Bahia: texto explicativo para o mapa geológico ao milionésimo. Salvador: SICM, SGM, p. 85-102.

Singh A.K., Tewaril V.C., Sial A.N., Khanna P.P., Singh N.I. 2015. Rare earth elements and stable isotope geochemistry of carbonates from the mélange zone of Manipur ophiolitic Complex, Indo-Myanmar Orogenic Belt, Northeast India. Carbonates and Evaporites, 31:139-151. https://doi. org/10.1007/s13146-015-0249-2

Soares G.G., Van Kranendonk V.J., Belousova E., Thomson S. 2019. Phosphogenesis in the immediate aftermath of the Great Oxidation Event: Evidence from the Turee Creek Group, Western Australia. Precambrian Research, 320:193-212. https://doi.org/10.1016/j.precamres.2018.10.017

Stacey S., Kramers J.D. 1975. Approximation of terrestrial lead isotope evolution by a two stage model. Earth and Planetary Science Letters, 26(2):207-221. https://doi.org/10.1016/0012-821X(75)90088-6

Sverjensky D.A. 1984. Europium redox equilibria in aqueous solution. Earth and Planetary Science Letters, 67(1):70-78. https://doi. org/10.1016/0012-821X(84)90039-6

Swart P.K. 2015. The geochemistry of carbonates diagenesis: The past, present and future. Sedimentology, 62(5):1233-1304. https://doi. org/10.1111/sed.12205

Tang L., Santosh M., Tsunogae T., Maruoka T. 2016. Paleoproterozoic meta-carbonates from the central segment of the Trans-North China Orogen: Zircon U-Pb geochronology, geochemistry, and carbon and oxygen isotopes. Precambrian Research, 284:14-29. https://doi.org/10.1016/j. precamres.2016.08.001

Taylor S.R., McLennan S.M. 1985. The Continental Crust: Its composition and evolution; an examination of the geochemical record preserved in sedimentary rocks. Oxford: Blackwell Scientific Oxford, $312 \mathrm{p}$

Tostevin R., Shields G.A., Tarbuck G.M., He T., Clarkson M.O, Wood R.A. 2016. Effective use of cerium anomalies as a redox proxy incarbonatedominated marine settings. Chemical Geology, 438:146-162. https://doi. org/10.1016/j.chemgeo.2016.06.027

Van Kranendonk M.J., Webb G.E., Kamber B.S. 2003. Geological and trace element evidence for a marine sedimentary environment of deposition and biogenicity of 3.45 Ga stromatolitic carbonates in the Pilbara Craton, and support for a reducing Archean ocean. Geobiology, 1(2):91-108. https:// doi.org/10.1046/j.1472-4669.2003.00014.x

Veizer J., Ala D., Azmy K., Bruckschen P., Buhl D., Bruhn F., Carden G.A.F., Diener A., Ebneth S., Godderis Y., Jasper T., Korte C., Pawellek F., Podlaha O.G., Strauss H. 1999. 87Sr/86Sr, $\beta 13$ Cand $\beta 180$ Evolution Plhanerozoic seawater. Chemical Geology, 161:59-88.

Wang W., Bolhar R., Zhou M., Zhao X. 2018. Enhanced terrestrial input into Paleoproterozoic to Mesoproterozoic carbonates in the southwestern South China Block during the fragmentation of the Columbia supercontinent. Precambrian Research, 313:1-17. https://doi.org/10.1016/j. precamres.2018.05.001

Webb G.E., Kamber B.S. 2000. Rare earth elements in Holocene reefal microbialites: A new shallow seawater proxy. Geochimica et Cosmochimica Acta, 64(9):1557-1565. https://doi.org/10.1016/ S0016-7037(99)00400-7

Windley B.F. 1984. The evolving continent. 2. ed. Chichester: John Wiley \& Sons, $391 \mathrm{p}$

Winkler H.G.F. 1979. Petrogenesis of metamorphic rocks. New York: SpringerVerlag, 348 p.

Winter J.D. 2001. An introduction to igneous and metamorphic petrology. Upper Saddle River, Prentice Hall. 
Braz. J. Geol. (2021), 51(3): e20190137

Yardley B.W.D. 1989. Introdução à Petrologia Metamórfica. 2. ed. Brasília: Ed. UnB, p. 215-248.

Zhao Y.Y., Zhao M-Y., Li S-Z. 2018. Evidences of hydrothermal fluids recorded in microfacies of the Ediacaran cap dolostone: Geochemical implications in South China. Precambrian Research, 306:1-21. https://doi. org/10.1016/j.precamres.2017.12.028

Zhao Y., Zheng Y. 2013. Geochemical constraints on the origin of posdepositional fluids in sedimentary carbonates of the Ediacaran system in South China. Precambrian Research, 224:341-363. https://doi. org/10.1016/j.precamres.2012.10.014

Zhao Y., Zheng Y., Chen F.K. 2009. Trace element and strontium isotioe constraints on sedimentar environment of Ediacaran carbonates in Southern Anhui, South China. Chemical Geology, 265(3-4):345-362. https://doi. org/10.1016/j.chemgeo.2009.04.015
Zhong S., Mucci A. 1995. Partitioning of rare earth elements (REEs) between calcite and seawater solutions at $25^{\circ} \mathrm{C}$ and $1 \mathrm{~atm}$, and high dissolved REE concentrations. Geochimica et Cosmochimica Acta, 59(3):443-453. https://doi.org/10.1016/0016-7037(94)00381-U

Zhu B., Jiang S.Y., Yang J.H., Pi D., Ling H.F., Chen Y.Q. 2014. Rare earth element and Sr-Nd isotope geochemistry of phosphate nodules from the lower Cambrian Niutitang Formation, NW Hunan Province, South China. Palaeogeography, Palaeoclimatology, Palaeoecology, 398:132-143. https://doi. org/10.1016/j.palaeo.2013.10.002

Zhu B., Jiang S.Y. 2017. A LA-ICP-MS analysis of rare earth elements on phosphatic grains of the Ediacaran Doushantuo phosphorite at Weng'an, South China: implication for depositional conditions and diagenetic processes. Geological Magazine, 154(6):1-17. https://doi.org/10.1017/ S001675681700022X 